\title{
Chemical cycling and deposition of atmospheric mercury in polar regions: review of recent measurements and comparison with models
}

\author{
Hélène Angot $^{1}$, Ashu Dastoor ${ }^{2}$, Francesco De Simone ${ }^{3}$, Katarina Gårdfeldt ${ }^{4}$, Christian N. Gencarelli ${ }^{3}$, \\ Ian M. Hedgecock ${ }^{3}$, Sarka Langer ${ }^{5}$, Olivier Magand ${ }^{6,1}$, Michelle N. Mastromonaco ${ }^{4}$, Claus Nordstrøm ${ }^{7}$, \\ Katrine A. Pfaffhuber ${ }^{8}$, Nicola Pirrone ${ }^{9}$, Andrei Ryjkov ${ }^{2}$, Noelle E. Selin ${ }^{10,11}$, Henrik Skov ${ }^{7}$, Shaojie Song ${ }^{10}$, \\ Francesca Sprovieri ${ }^{3}$, Alexandra Steffen ${ }^{12}$, Kenjiro Toyota ${ }^{12}$, Oleg Travnikov ${ }^{13}$, Xin Yang ${ }^{14}$, and \\ Aurélien Dommergue ${ }^{1,6}$ \\ ${ }^{1}$ Univ. Grenoble Alpes, Laboratoire de Glaciologie et Géophysique de l'Environnement (LGGE), 38041 Grenoble, France \\ ${ }^{2}$ Air Quality Research Division, Environment and Climate Change Canada, Dorval, Québec H9P 1J3, Canada \\ ${ }^{3}$ CNR-Institute of Atmospheric Pollution Research, Division of Rende, UNICAL-Polifunzionale, 87036 Rende, Italy \\ ${ }^{4}$ Department of Chemistry and Chemical Engineering, Chalmers University of Technology 41296 Göteborg, Sweden \\ ${ }^{5}$ IVL Swedish Environmental Research Institute, P.O. Box 530 21, 40014 Göteborg, Sweden \\ ${ }^{6}$ CNRS, Laboratoire de Glaciologie et Géophysique de l'Environnement (LGGE), 38041 Grenoble, France \\ ${ }^{7}$ National Environmental Research Institute, Frederiksborgvej 399, 4000 Roskilde, Denmark \\ ${ }^{8}$ Norwegian Institute for Air Research (NILU), P.O. Box 100, 2027 Kjeller, Norway \\ ${ }^{9}$ CNR-Institute of Atmospheric Pollution Research, Area della Ricerca di Roma 1, Monterotondo, 00015 Rome, Italy \\ ${ }^{10}$ Department of Earth, Atmospheric and Planetary Sciences, Massachusetts Institute of Technology, Cambridge, MA, USA \\ ${ }^{11}$ Institute for Data, Systems, and Society, Massachusetts Institute of Technology, Cambridge, MA, USA \\ ${ }^{12}$ Air Quality Research Division, Environment and Climate Change Canada, Toronto, Ontario M3H 5T4, Canada \\ ${ }^{13}$ Meteorological Synthesizing Centre, East of EMEP, 2nd Roshchinsky proezd, 8/5, 115419 Moscow, Russia \\ ${ }^{14}$ British Antarctic Survey, Cambridge, UK
}

Correspondence to: Aurélien Dommergue (aurelien.dommergue@univ-grenoble-alpes.fr)

Received: 14 June 2016 - Published in Atmos. Chem. Phys. Discuss.: 16 June 2016

Revised: 12 August 2016 - Accepted: 17 August 2016 - Published: 30 August 2016

\begin{abstract}
Mercury ( $\mathrm{Hg})$ is a worldwide contaminant that can cause adverse health effects to wildlife and humans. While atmospheric modeling traces the link from emissions to deposition of $\mathrm{Hg}$ onto environmental surfaces, large uncertainties arise from our incomplete understanding of atmospheric processes (oxidation pathways, deposition, and re-emission). Atmospheric $\mathrm{Hg}$ reactivity is exacerbated in high latitudes and there is still much to be learned from polar regions in terms of atmospheric processes. This paper provides a synthesis of the atmospheric $\mathrm{Hg}$ monitoring data available in recent years (2011-2015) in the Arctic and in Antarctica along with a comparison of these observations with numerical simulations using four cutting-edge global models. The cycle of atmospheric $\mathrm{Hg}$ in the Arctic and in Antarctica presents both similarities and differences. Coastal sites in the two re-
\end{abstract}

gions are both influenced by springtime atmospheric $\mathrm{Hg}$ depletion events and by summertime snowpack re-emission and oceanic evasion of $\mathrm{Hg}$. The cycle of atmospheric $\mathrm{Hg}$ differs between the two regions primarily because of their different geography. While Arctic sites are significantly influenced by northern hemispheric $\mathrm{Hg}$ emissions especially in winter, coastal Antarctic sites are significantly influenced by the reactivity observed on the East Antarctic ice sheet due to katabatic winds. Based on the comparison of multi-model simulations with observations, this paper discusses whether the processes that affect atmospheric $\mathrm{Hg}$ seasonality and interannual variability are appropriately represented in the models and identifies research gaps in our understanding of the atmospheric $\mathrm{Hg}$ cycling in high latitudes. 


\section{Introduction}

Mercury $(\mathrm{Hg})$ can be emitted to the atmosphere by natural geological sources (e.g., volcanic emissions) and a variety of anthropogenic activities (e.g., coal combustion, artisanal and small-scale gold mining) (UNEP, 2013a). The dominant form of atmospheric mercury is gaseous elemental mercury $(\mathrm{Hg}(0))$ (Lindberg and Stratton, 1998). $\mathrm{Hg}(0)$ has an atmospheric lifetime of 0.5 to 1 year (Selin, 2009) and can therefore be transported worldwide. It can be oxidized into highly reactive and water-soluble gaseous and particulate divalent species ( $\mathrm{Hg}(\mathrm{II})$ and $\mathrm{Hg}(\mathrm{p})$, respectively) that can deposit onto environmental surfaces (e.g., land, surface oceans) through wet and dry processes (Lindqvist and Rodhe, 1985). Upon deposition, mercury can be re-emitted to the atmosphere or converted - in aquatic systems - to methylmercury (Driscoll et al., 2013). Anthropogenic activities have altered the global geochemical cycle of mercury, enhancing the amount of mercury circulating in the atmosphere and surface oceans by at least a factor of 3 (Lamborg et al., 2014; Amos et al., 2015).

Methylmercury is a worldwide contaminant of seafood that can cause adverse effects on the developing nervous system of vulnerable populations (AMAP, 2015). The Minamata Convention on mercury - a global treaty to protect human health and the environment from mercury - was opened for signature in October 2013 (UNEP, 2013b). To date, the Convention has been signed by 128 countries and ratified by 29 . It will enter into force once it is ratified by 50 nations. As noted in the preamble of the Convention, Arctic ecosystems and indigenous communities are particularly vulnerable due to the biomagnification of mercury and contamination of traditional foods. In order to reduce mercury effects, the pathway from emissions to human and environmental impacts needs to be traced. Atmospheric modeling provides a first step by tracing the link from emissions to deposition onto environmental surfaces. Deposition of mercury in a particular region depends on the magnitude and speciation of domestic and foreign emissions and on the oxidative capacity of the atmosphere that transforms $\mathrm{Hg}(0)$ to deposited divalent species (UNEP, 2015). Deposition is partly offset by the revolatilization of a fraction of deposited mercury. Large uncertainties associated with the models arise as a result of our incomplete understanding of atmospheric processes (e.g., oxidation pathways, deposition, and re-emission) (Kwon and Selin, 2016). Atmospheric mercury reactivity is exacerbated in high latitudes and there is still much to be learned from polar regions in terms of atmospheric processes.

First discovered in 1995 (Schroeder et al., 1998), atmospheric mercury depletion events (AMDEs) are observed in springtime throughout the Arctic (Lindberg et al., 2001; Berg et al., 2003a; Poissant and Pilote, 2003; Skov et al., 2004; Steffen et al., 2005) as a result of the oxidation of $\operatorname{Hg}(0)$ by reactive bromine species (Lu et al., 2001; Brooks et al., 2006; Sommar et al., 2007). AMDEs can lead to a deposition of $\sim 100 \mathrm{t}$ of mercury per year to the Arctic (Ariya et al., 2004; Skov et al., 2004; Dastoor et al., 2015). The fate of mercury deposited onto the snowpack during AMDEs is still a matter of debate in the scientific mercury community (Steffen et al., 2008). Several studies reported significant reemission (e.g., Ferrari et al., 2005; Brooks et al., 2006; Kirk et al., 2006; Sommar et al., 2007; Dommergue et al., 2010a) although a fraction of mercury may likely accumulate within the snowpack (Hirdman et al., 2009; Larose et al., 2010). While the Arctic has been extensively monitored - with hundreds of publications focusing on AMDEs - measurements are sporadic in Antarctica. To the best of the author's knowledge, only 11 studies dealing with atmospheric mercury in Antarctica (and using modern instrument) have been published (Ebinghaus et al., 2002; Sprovieri et al., 2002; Temme et al., 2003; Brooks et al., 2008a, b; Dommergue et al., 2012; Pfaffhuber et al., 2012; Angot et al., 2016a, b; Nerentorp Mastromonaco et al., 2016; Wang et al., 2016). The earliest studies showed the occurrence of AMDEs in coastal Antarctica after polar sunrise. The latest studies highlighted new atmospheric processes in the Antarctic boundary layer - both in winter and summertime - leading to the formation and subsequent deposition of reactive mercury. In the meantime, several studies showed that the Antarctic Plateau plays a key role in influencing the cycle of atmospheric mercury at a continental scale.

The first objective of this paper is to provide a synthesis of the atmospheric mercury monitoring data available in recent years (2011-2015) in polar regions. Secondly, we provide a comparison of these observations with numerical simulations of atmospheric mercury concentrations using cutting-edge global models. Finally, this paper identifies research gaps in our understanding and modeling of the atmospheric mercury cycling in high latitudes.

\section{Experimental section}

\subsection{Measurements of atmospheric mercury species}

\subsubsection{Definitions}

$\mathrm{Hg}(0), \mathrm{Hg}(\mathrm{II})$, and $\mathrm{Hg}(\mathrm{p})$ are the most abundant mercury species in the atmosphere. Atmospheric $\operatorname{Hg}(0)$ is easily and accurately measured in polar regions (Steffen et al., 2008; Dommergue et al., 2010b). $\mathrm{Hg}$ (p) and reactive gaseous mercury (RGM) - the latter consisting of various gaseous $\mathrm{Hg}$ (II) compounds - are operationally defined. Total gaseous mercury (TGM) refers to the sum of $\mathrm{Hg}(0)$ and $\mathrm{Hg}(\mathrm{II})$, and reactive mercury (RM) to the sum of RGM and $\mathrm{Hg}(\mathrm{p})$.

\subsubsection{Instrumentation}

Measurements of atmospheric mercury species were performed at various sites in the Arctic and in Antarctica over the 2011-2015 period (Fig. 1). All $\mathrm{Hg}(0)$ measurements reported in this paper were performed using a Tekran gas-phase 
analyzer (Model 2537), and all RGM and $\mathrm{Hg}(\mathrm{p})$ measurements using a Tekran speciation unit (1130/1135) (Table 1). The Tekran 2537 analyzer is based on the amalgamation of mercury onto a gold cartridge followed by a thermal desorption and detection by an integrated cold vapor atomic fluorescence spectrometer (CVAFS) at $253.7 \mathrm{~nm}$ (Fitzgerald and Gill, 1979; Bloom and Fitzgerald, 1988). The analysis of $\mathrm{Hg}(0)$ is semi-continuous and the presence of two gold cartridges allows alternating sampling and desorption modes. At all sampling sites, the sample air stream was prefiltered either through a Tekran speciation unit or through a soda lime trap and/or a PTFE (polytetrafluoroethylene) filter (Table 1). Some researchers report ambient air collected at polar sites as TGM (Ebinghaus et al., 2002), instead of $\mathrm{Hg}(0)$, but the PTFE filter on the front of the analyzer inlet most likely removes RGM and thus only $\mathrm{Hg}(0)$ is collected and analyzed (Steffen et al., 2002, 2008). Due to the extremely cold and dry air in Antarctica, no heated sampling line was used and no soda lime was applied at Troll (TR), Dome C (DC), and Dumont d'Urville (DDU). Collected at 5 to $15 \mathrm{~min}$ intervals at the various sites, $\operatorname{Hg}(0)$ measurements are reported here as hourly averages. RGM and $\mathrm{Hg}(\mathrm{p})$ measurements at ALT and ANT were performed using a Tekran speciation unit - connected to a 2537 analyzer through a PTFE heated sampling line - through a multistep procedure as described elsewhere (Lindberg et al., 2002) using an impactor inlet (2.5 $\mu \mathrm{m}$ cut-off aerodynamic diameter at $10 \mathrm{~L} \mathrm{~min}^{-1}$ ), a $\mathrm{KCl}$-coated quartz annular denuder in the 1130 unit, and a quartz regenerable particulate filter (RPF) in the 1135 unit.

\subsubsection{Quality assurance and quality control procedures}

Auto-calibrations of the 2537 analyzers were performed every 25 to $72 \mathrm{~h}$ at the various sites using an internal mercury permeation source. The accuracy of this permeation source was checked at least once per year against manual injections using a Tekran 2505 mercury vapor calibration unit and following a strict procedure adapted from Dumarey et al. (1985). The detection limit for $\mathrm{Hg}(0)$ measurements is $0.10 \mathrm{ng} \mathrm{m}^{-3}$ according to the instrument manual (Tekran, 2011). Based on experimental evidence, the average systematic uncertainty for $\mathrm{Hg}(0)$ measurements is of $\sim 10 \%$ (Slemr et al., 2015). There is no robust calibration technique of the Tekran speciation unit and no certified reference material available. There is growing evidence that RGM and $\mathrm{Hg}(\mathrm{p})$ might suffer from significant biases and interferences (Lyman et al., 2010; Gustin et al., 2013; Jaffe et al., 2014; Huang et al., 2013; Kos et al., 2013) and that RGM concentrations might be underestimated by as much as a factor of 2-13 (Gustin et al., 2016). Despite these limitations, the Tekran speciation unit is currently the best available automated method, and $\mathrm{Hg}(\mathrm{p})$ and RGM measurements can be used as first estimates to evaluate atmospheric models. Maintenance operations on the Tekran 2537/1130/1135 instruments and screening criteria for data validation/invalidation were performed according to the directives of the standard operational procedure from CAMNet (Canadian Mercury Measurement Network), AMNet (United States Atmospheric Mercury Network), or GMOS (Global Mercury Observation System) (Steffen et al., 2012; D’Amore et al., 2015).

\subsection{Global mercury simulations}

The current study is based on multi-model simulations performed as part of the Mercury Modeling Task Force (MMTF) under the GMOS project (Travnikov et al., 2016). Four global models (ECHMERIT, GEM-MACH-Hg, the mercury version of the Global Environmental Multi-scale, Modelling air quality and Chemistry model, GEOS-Chem, and GLEMOS, the Global EMEP Multi-media Modelling System) were applied for evaluating monthly-averaged atmospheric mercury concentrations and deposition at various Arctic and Antarctic ground-based sites for the year 2013. Additionally, GEM-MACH-Hg and GEOS-Chem provided hourlyaveraged data from 2011 to 2014 to allow investigations of interannual variability. A brief description of the parameterization of the four models is given below. The models differ significantly in their description of mercury atmospheric chemistry and their parameterization of processes specific to polar regions (i.e., AMDEs, oceanic evasion, and re-emissions from the snowpack).

\subsubsection{ECHMERIT}

ECHMERIT is a fully coupled model, based on the atmospheric general circulation model ECHAM5, and a mercury chemistry module, developed at the Institute for Atmospheric Pollution of the National Research Council (CNR-IIA) of Italy (Jung et al., 2009; De Simone et al., 2014, 2016). The base mechanism includes oxidation of $\mathrm{Hg}(0)$ by $\mathrm{OH}$ and $\mathrm{O}_{3}$ in the gas and aqueous (in-cloud) phases (Reactions R1 to R3). Rate constants of Reactions (R1) to (R3) are from Sommar et al. (2001), Hall (1995), and Munthe (1992), respectively.

$\mathrm{Hg}(0)+\mathrm{OH} \rightarrow \mathrm{Hg}(\mathrm{II})$

$\mathrm{Hg}(0)+\mathrm{O}_{3} \rightarrow \mathrm{Hg}(\mathrm{II})$

$\mathrm{Hg}(0)_{(\mathrm{aq})}+\mathrm{O}_{3(\mathrm{aq})} \rightarrow \mathrm{Hg}(\mathrm{II})_{(\mathrm{aq})}$

Oxidant fields $\left(\mathrm{OH} / \mathrm{O}_{3}\right)$ are imported from MOZART (Model for Ozone and Related Chemical Tracers) (Emmons et al., 2010). In the base run used for this work bromine chemistry is not included, and there is no parameterization of AMDEs. ECHMERIT implements dynamically calculated ocean emissions for all ice-free basins, including polar regions, as described in De Simone et al. (2014), and a prompt re-emission of $60 \%$ of deposited mercury over ice (Selin et al., 2008). 
(a)

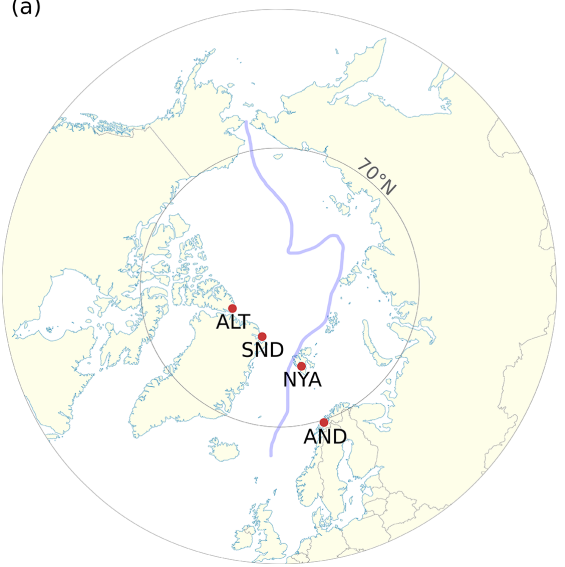

(b)

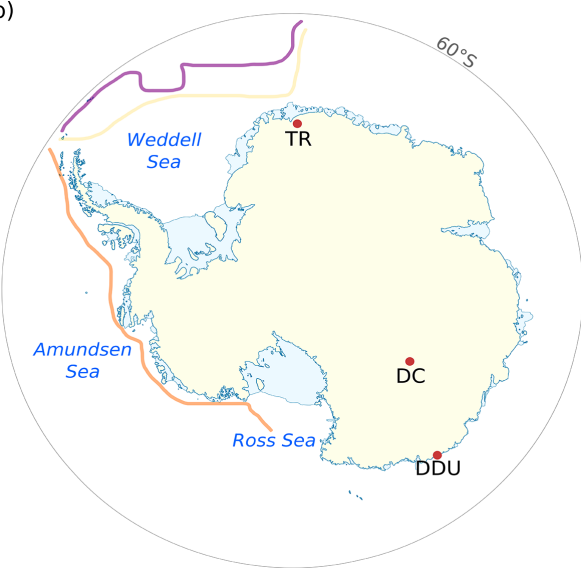

Figure 1. Location of (a) Arctic and (b) Antarctic ground-based sites whose data are reported in this paper: Alert (ALT), Villum Research Station at Station Nord (SND), Zeppelin station at Ny-Ålesund (NYA), Andøya (AND), Troll (TR), Concordia Station at Dome C (DC), and Dumont d'Urville (DDU). Additionally, the approximate path of cruises performed in recent years (2011-2015) is given: CHINARE 2012 in the Arctic on board the Chinese vessel Xuelong (in blue), ANT XXIX/6-7 (denoted ANT in the paper) over the Weddell Sea on board icebreaker R/V Polarstern (in yellow and purple), and OSO 10/11 (denoted OSO in the paper) over Ross and Amundsen Seas on board icebreaker Oden (in orange).

Table 1. Summary of the instrumentation used at the various polar sites to measure atmospheric mercury species.

\begin{tabular}{|c|c|c|c|c|c|c|c|}
\hline Code & Elevation & Analyte & Instrumentation & $\begin{array}{l}\text { Flow rate } \\
(\mathrm{L} \mathrm{min}-1)\end{array}$ & Resolution & Filter & Sampling line \\
\hline \multicolumn{8}{|c|}{ Arctic sites } \\
\hline \multirow[t]{2}{*}{ ALT } & 195 & $\mathrm{Hg}(0)$ & Tekran 2537A & 1.0 & $5 \mathrm{~min}$ & speciation unit & heated \\
\hline & & $\operatorname{Hg}(\mathrm{p}), \mathrm{RGM}$ & 1130 and 1135 & 10.0 & $2 \mathrm{~h}$ & & \\
\hline SND & 30 & $\mathrm{Hg}(0)$ & Tekran 2537A & 1.5 & $5 \mathrm{~min}$ & soda lime & heated \\
\hline NYA & 474 & $\mathrm{Hg}(0)$ & Tekran 2537A & 1.5 & $5 \mathrm{~min}$ & $2 \mu \mathrm{m}$ PTFE, soda lime & heated \\
\hline AND & 10 & $\mathrm{Hg}(0)$ & Tekran 2537A & 1.5 & $5 \mathrm{~min}$ & $2 \mu \mathrm{m}$ PTFE, soda lime & heated \\
\hline \multicolumn{8}{|c|}{ Antarctic sites } \\
\hline TR & 1275 & $\operatorname{Hg}(0)$ & Tekran 2537A & 1.5 & $5 \mathrm{~min}$ & $2 \mu \mathrm{m}$ PTFE & unheated \\
\hline DC & 3220 & $\mathrm{Hg}(0)$ & Tekran 2537A & 0.8 & $5-15 \mathrm{~min}$ & 0.45 PTFE & unheated \\
\hline DDU & 43 & $\mathrm{Hg}(0)$ & Tekran 2537B & 1.0 & $10-15 \mathrm{~min}$ & 0.20 PTFE & unheated \\
\hline \multirow[t]{2}{*}{ ANT } & 20 & $\mathrm{Hg}(0)$ & Tekran 2537A & 1.0 & $5 \mathrm{~min}$ & speciation unit & heated \\
\hline & & $\operatorname{Hg}(p)$, RGM & 1130 and 1135 & 10.0 & $2 \mathrm{~h}$ & & \\
\hline OSO & 15 & $\mathrm{Hg}(0)$ & Tekran 2537A & 1.0 & $5 \mathrm{~min}$ & 0.45 PTFE & unheated \\
\hline
\end{tabular}

\subsubsection{GEM-MACH-Hg}

GEM-MACH-Hg is a mercury version of the Environment and Climate Change Canada's (ECCC's) current operational air-quality forecast model GEM-MACH. GEM-MACH-Hg is an online model, meaning that the meteorology is simulated in-step with the chemistry, and includes representation of physicochemical processes of mercury based on the ECCC's previous mercury model, GRAHM (Dastoor and Larocque, 2004; Dastoor et al., 2008, 2015; Durnford et al., 2010, 2012; Kos et al., 2013). The horizontal resolution of the model for this study is $1^{\circ} \times 1^{\circ}$ latitude/longitude. $\operatorname{Hg}(0)$ is oxidized in the atmosphere by $\mathrm{OH}$ (Reaction R1) and bromine (Reactions (R4) to (R6), $\mathrm{X}=\mathrm{Br}$ or $\mathrm{BrO}$ ). The rate constant of Reaction (R1) is from Sommar et al. (2001), but scaled down by a coefficient of 0.34 to take into account possible dissociation reactions (Tossell, 2003; Goodsite et al., 2004). Rate constants of Reactions (R4) to (R6) are from Donohoue et al. (2006), Dibble et al. (2012), and Goodsite et al. (2004), respectively. Aqueous-phase reduction reactions are not included.

$$
\begin{aligned}
& \mathrm{Hg}(0)+\mathrm{Br} \rightarrow \mathrm{Hg}(\mathrm{I}) \mathrm{Br} \\
& \mathrm{Hg}(\mathrm{I}) \mathrm{Br} \rightarrow \mathrm{Hg}(0)+\mathrm{Br} \\
& \mathrm{Hg}(\mathrm{I}) \mathrm{Br}+\mathrm{X} \rightarrow \mathrm{Hg}(\mathrm{II}) \mathrm{X}
\end{aligned}
$$


OH fields are from MOZART (Emmons et al., 2010) while $\mathrm{BrO}$ is derived from 2007-2009 satellite observations of $\mathrm{BrO}$ vertical columns. The associated $\mathrm{Br}$ concentration is then calculated from photochemical steady state according to Eq. (1), where $\mathrm{J}_{\mathrm{BrO}}$ is the $\mathrm{BrO}$ photolysis frequency and $\mathrm{k}_{1}=2.1 \times 10^{-11} \mathrm{~cm}^{3}$ molecule ${ }^{-1} \mathrm{~s}^{-1}$ and $\mathrm{k}_{2}=1.2 \times$ $10^{-12} \mathrm{~cm}^{3}$ molecule $\mathrm{s}^{-1}$ are the rate coefficients for the $\mathrm{BrO}+\mathrm{NO} \rightarrow \mathrm{Br}+\mathrm{NO}_{2}$ and $\mathrm{Br}+\mathrm{O}_{3} \rightarrow \mathrm{BrO}+\mathrm{O}_{2}$ reactions, respectively (Platt and Janssen, 1995).

$$
\frac{[\mathrm{Br}]}{[\mathrm{BrO}]}=\frac{J_{\mathrm{BrO}}+k_{1}[\mathrm{NO}]}{k_{2}\left[\mathrm{O}_{3}\right]}
$$

Durnford et al. (2012) developed and implemented a dynamic multilayer snowpack/meltwater parameterization allowing the representation of deposition and re-emission of mercury. Oceanic evasion of $\operatorname{Hg}(0)$ is activated if there is open water and the temperature at the air-sea interface is $-4{ }^{\circ} \mathrm{C}$ or greater (Dastoor and Durnford, 2014). In addition, $\mathrm{Hg}(0)$ released from sea-ice melting is also taken into account. The parameterization of AMDEs is based on $\mathrm{Br}$ production and chemistry and snow re-emission of $\mathrm{Hg}(0)$ (Dastoor et al., 2008).

\subsubsection{GEOS-Chem}

GEOS-Chem (v9-02) is a global chemical transport model driven by assimilated meteorological data from the NASA GMAO Goddard Earth Observing System (Bey et al., 2001). It couples a 3-D atmosphere (Holmes et al., 2010), a 2-D mixed layer slab ocean (Soerensen et al., 2010), and a 2-D terrestrial reservoir (Selin et al., 2008) with a horizontal resolution of $2^{\circ} \times 2.5^{\circ}$ latitude/longitude. Three mercury tracers $(\mathrm{Hg}(0), \mathrm{Hg}(\mathrm{II})$, and $\mathrm{Hg}(\mathrm{p}))$ are tracked in the atmosphere (Amos et al., 2012). Mercury fluxes at terrestrial and ocean surfaces are described in Song et al. (2015). A two-step oxidation mechanism initialized by $\mathrm{Br}$ atoms is used (Reactions (R4) to (R6), $\mathrm{X}=\mathrm{Br}$ or $\mathrm{OH}$ ). $\mathrm{Br}$ fields are archived from a full-chemistry GEOS-Chem simulation (Parrella et al., 2012) while rate constants of Reactions (R4) to (R6) are from Donohoue et al. (2006), Balabanov et al. (2005), and Goodsite et al. (2012), respectively. Some model setups related to polar regions are implemented in v9-02 of the model as described in details in Holmes et al. (2010). 5 pptv of $\mathrm{BrO}$ - at the low end of concentrations reported by Neuman et al. (2010) - is added in the springtime Arctic (Antarctic) boundary layer during March-May (August-October) over areas with sea ice, sunlight, stable conditions, and temperatures below $-5^{\circ} \mathrm{C}$. The associated $\mathrm{Br}$ concentration is then calculated from photochemical steady state according to Eq. (1), assuming that $\mathrm{O}_{3}$ is depleted to 2 ppbv. Additionally, a snowpack reservoir is added. It accumulates deposited mercury and releases it as $\operatorname{Hg}(0)$ under sunlit conditions in a temperature-dependent way.

\subsubsection{GLEMOS}

GLEMOS is a multi-scale chemical transport model developed for the simulation of environmental dispersion and cycling of different chemicals including mercury (Travnikov and Ilyin, 2009). The model simulates atmospheric transport, chemical transformations, and deposition of three mercury species $(\mathrm{Hg}(0), \mathrm{Hg}(\mathrm{II})$, and $\mathrm{Hg}(\mathrm{p}))$. The atmospheric transport of tracers is driven by meteorological fields generated by the Weather Research and Forecast (WRF) modeling system (Skamarock et al., 2007) fed by the operational analysis data from ECMWF. The model in the base configuration has a horizontal resolution of $1^{\circ} \times 1^{\circ}$. The base mechanism includes oxidation of $\mathrm{Hg}(0)$ by $\mathrm{OH}(\mathrm{R} 1)$ and $\mathrm{O}_{3}(\mathrm{R} 2)$ in the atmosphere. Rate constants are from Sommar et al. (2001) and Hall (1995), respectively. The model also includes incloud oxidation of $\mathrm{Hg}(0)$ by $\mathrm{OH}, \mathrm{O}_{3}$, and $\mathrm{Cl}$ with associated rate constants from Gårdfeldt et al. (2001), Munthe (1992), and Lin and Pehkonen (1999), respectively. In-cloud reduction by $\mathrm{SO}_{3}^{2-}$ is also implemented, with an associated rate constant from Petersen et al. (1998). Reactant fields are imported from MOZART (Emmons et al., 2010).

The parameterization of AMDEs in polar regions is based on $\mathrm{Br}$ chemistry following the two-step mechanism (R4)(R6) described in Holmes et al. (2010). Br concentrations are extracted from p-TOMCAT (parallel-Tropospheric OffLine Model of Chemistry and Transport) results (Yang et al., 2005). GLEMOS includes an empirical parameterization of prompt re-emission from snow. It is assumed that re-emission occurs only from newly deposited mercury in the presence of solar radiation. Two competing processes are considered: photoreduction and ageing of deposited mercury with the characteristic times of 1 and 10 days, respectively. It is also assumed that all reduced mercury is immediately re-emitted back to the atmosphere. The aged fraction of mercury does not undergo reduction and is accumulated within the snowpack. No mercury evasion from the ocean is implemented.

\subsection{Goodness-of-fit statistics between modeled and observed data}

The Nash-Sutcliffe efficiency (NSE; Nash and Sutcliffe, 1970) indicates how well the plot of observed versus simulated data fits the $1: 1$ line - NSE $=1$ corresponding to the perfect match. NSE is defined as 1 minus the sum of the absolute squared differences between the simulated and observed values normalized by the variance of the observed values:

$\mathrm{NSE}=1-\frac{\sum_{i=1}^{N}\left(O_{i}-S_{i}\right)^{2}}{\sum_{i=1}^{N}\left(O_{i}-\bar{O}\right)^{2}}$.

The root mean square error (RMSE) gives the standard deviation of the model prediction error (in the same units of sim- 
ulated and observed values). A smaller value indicates better model performance. It is calculated as follows:

$\mathrm{RMSE}=\sqrt{\frac{1}{N} \sum_{i=1}^{N}\left(S_{i}-O_{i}\right)^{2}}$

The percent bias (PBIAS, in \%) measures the average tendency of the simulated values to be larger or smaller than their observed ones. The optimal value of PBIAS is 0. PBIAS is calculated as follows:

PBIAS $=100 \frac{\sum_{i=1}^{N}\left(S_{i}-O_{i}\right)}{\sum_{i=1}^{N} O_{i}}$.

NSE, RMSE, and PBIAS were calculated by using the $\mathrm{R}$ package "hydroGOF" (Zambrano-Bigiarini, 2014).

\section{Results and discussion}

\subsection{Arctic sites}

\subsubsection{Observations}

Figure 2a shows monthly box plots of all data collected at the four Arctic sites. The average $\operatorname{Hg}(0)$ value in the Arctic over the 2011-2014 period is $1.46 \pm 0.33 \mathrm{ng} \mathrm{m}^{-3}$. This concentration falls within the range of what is observed in the Northern Hemisphere (Sprovieri et al., 2016b). The highest mean is at AND $\left(1.55 \pm 0.15 \mathrm{ng} \mathrm{m}^{-3}\right.$ over the 20112015 period), which is closer to European industrialized areas than other sites and experiences less frequent and pronounced AMDEs in spring (see below). There is a clear $\mathrm{Hg}(0)$ concentration gradient (except from June to August): AND $>$ NYA $>$ SND $>$ ALT.

The $\operatorname{Hg}(0)$ concentration data from the four Arctic sites for the period 2011-2015 are presented as monthly box and whisker plots in Fig. 3. Information regarding annually and monthly based statistics at the three sites can be found in Tables 2 and 3, respectively. The annual medians at NYA and AND (Table 2) suggest a low interannual variability in the distribution of $\operatorname{Hg}(0)$ concentrations. Conversely, there is a high degree of interannual variability at ALT and SND driven by the intensity of spring and summertime processes. This will be addressed in the following sections.

The mean seasonal variation of $\operatorname{Hg}(0)$ concentrations at ground-based Arctic sites is displayed in Fig. 4a. Summer refers to June-August, fall to September-November, winter to December-February, and spring to March-May. $\operatorname{Hg}(0)$ concentrations exhibit a strong and consistent seasonal pattern year after year, as already reported by others (Steffen et al., 2005; Berg et al., 2013). $\mathrm{Hg}(0)$ concentrations reach a distinct maximum in summer at ALT, SND, and NYA (mean concentrations of $1.63 \pm 0.37,1.63 \pm 0.37$, and

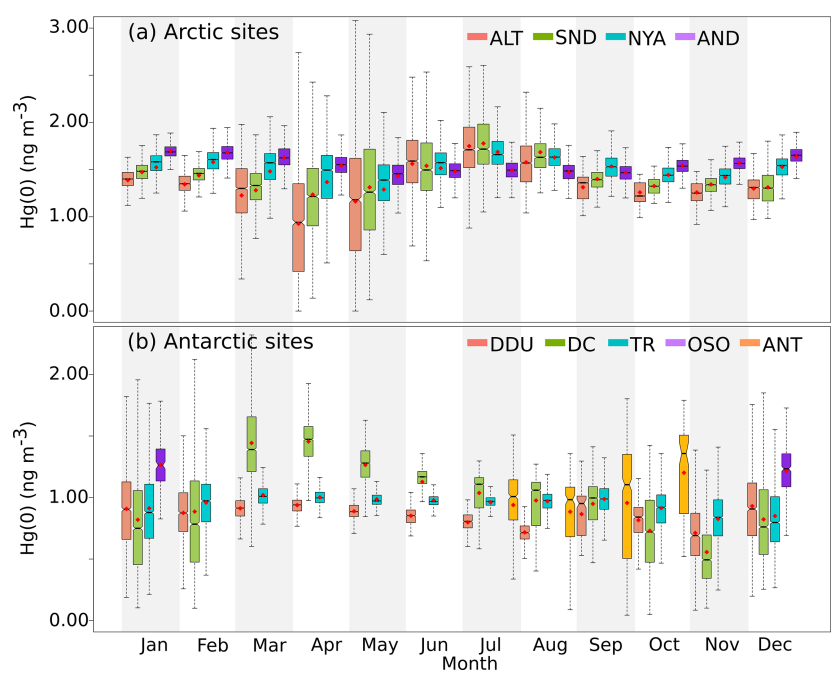

Figure 2. Box and whisker plots presenting the monthly $\mathrm{Hg}(0)$ concentration distribution at (a) Arctic ground-based sites - ALT (red), SND (green), NYA (turquoise), AND (purple) - and (b) Antarctic sites - DDU (red), DC (green), TR (turquoise) - during the OSO (purple) and ANT (orange) cruises. Red diamond: mean. Bottom and top of the box: first and third quartiles. Band inside the box: median. Ends of the whiskers: lowest (highest) datum still within the 1.5 interquartile range of the lowest (upper) quartile. Outliers are not represented.

$1.60 \pm 0.23 \mathrm{ng} \mathrm{m}^{-3}$, respectively). In late summer the concentrations start to decrease and reach in fall a mean value of $1.28 \pm 0.12 \mathrm{ng} \mathrm{m}^{-3}$ at ALT, $1.36 \pm 0.11 \mathrm{ng} \mathrm{m}^{-3}$ at SND, and $1.46 \pm 0.16 \mathrm{ng} \mathrm{m}^{-3}$ at NYA. In winter, concentrations increase slightly and are significantly higher than in fall at the three sites ( $p$ value $<0.0001$ at the three sites, MannWhitney test). Springtime reflects the lowest $\mathrm{Hg}(0)$ concentrations with mean values of $1.11 \pm 0.58 \mathrm{ng} \mathrm{m}^{-3}$ at ALT, $1.28 \pm 0.51 \mathrm{ng} \mathrm{m}^{-3}$ at SND, and $1.38 \pm 0.38 \mathrm{ng} \mathrm{m}^{-3}$ at NYA. The seasonal cycle is more pronounced at ALT than at SND and NYA. In contrast, lower concentrations were found in the Chukchi Sea in July $\left(1.17 \pm 0.38 \mathrm{ng} \mathrm{m}^{-3}\right)$ than in September $\left(1.51 \pm 0.79 \mathrm{ng} \mathrm{m}^{-3}\right)$ during the CHINARE 2012 expedition (Yu et al., 2014).

$\mathrm{Hg}(0)$ concentrations at AND exhibit an opposite seasonal cycle with a significantly ( $p$ value $<0.0001$, Mann-Whitney test) higher mean concentration in winter $\left(1.67 \pm 0.11 \mathrm{ng} \mathrm{m}^{-3}\right)$ than in summer $\left(1.48 \pm 0.12 \mathrm{ng} \mathrm{m}^{-3}\right)$, in line with the seasonality reported at Pallas, Finland $\left(67^{\circ} 22^{\prime} \mathrm{N}, 26^{\circ} 39^{\prime} \mathrm{E}\right)$ (Berg et al., 2001; Sprovieri et al., 2016b). The mechanisms which cause the seasonal variation of $\mathrm{Hg}(0)$ concentrations at Arctic sites are discussed in the following sections. 
Table 2. Annually based statistics (number of hourly-averaged data $(n)$, mean, median, standard deviation $(\mathrm{SD})$ ) of $\mathrm{Hg}(0)$ concentrations (in $\mathrm{ng} \mathrm{m}^{-3}$ ) at ground-based polar sites over the 2011-2015 period. Note that 2013 data at DC refer to concentrations recorded at $210 \mathrm{~cm}$ above the snowpack. The 2015 data coverage is May to June at SND and January to May at DDU (see Table 3). NA: not available due to QA/QC invalidation, instrument failure, or because the QA/QC validation is currently in progress (2015 data).

\begin{tabular}{lllllllll}
\hline & & ALT & SND & NYA & AND & TR & DC & DDU \\
\hline 2011 & $n$ & 8040 & 4712 & 8173 & 7444 & 5978 & NA & NA \\
& mean & 1.39 & 1.26 & 1.51 & 1.61 & 0.95 & NA & NA \\
& median & 1.35 & 1.34 & 1.59 & 1.61 & 0.99 & NA & NA \\
& SD & 0.45 & 0.32 & 1.61 & 0.15 & 0.20 & NA & NA \\
\hline \multirow{2}{*}{2012} & $n$ & 8447 & 7932 & 8181 & 8428 & 7808 & 3761 & 5949 \\
& mean & 1.21 & 1.44 & 1.51 & 1.61 & 0.98 & 0.76 & 0.91 \\
& median & 1.21 & 1.44 & 1.54 & 1.61 & 0.97 & 0.70 & 0.92 \\
& SD & 0.35 & 0.26 & 0.21 & 0.13 & 0.15 & 0.24 & 0.20 \\
\hline \multirow{2}{*}{2013} & $n$ & 8048 & 6605 & 6980 & 7862 & 8197 & 2900 & 5121 \\
& mean & 1.31 & 1.57 & 1.47 & 1.53 & 0.90 & 0.84 & 0.85 \\
& median & 1.39 & 1.49 & 1.52 & 1.56 & 0.93 & 0.87 & 0.85 \\
& SD & 0.46 & 0.44 & 0.30 & 0.15 & 0.15 & 0.27 & 0.19 \\
\hline & $n$ & 8358 & 4991 & 6730 & 8146 & 7421 & NA & 1958 \\
& mean & 1.45 & 1.36 & 1.48 & 1.50 & 0.95 & NA & 0.85 \\
& median & 1.45 & 1.36 & 1.57 & 1.51 & 1.00 & NA & 0.82 \\
& SD & 0.33 & 0.35 & 0.33 & 0.16 & 0.21 & NA & 0.38 \\
\hline \multirow{2}{*}{2015} & $n$ & NA & 1059 & 8342 & 7146 & 3670 & 8383 & 3114 \\
& mean & NA & 1.11 & 1.49 & 1.50 & 0.94 & 1.06 & 0.86 \\
& median & NA & 1.11 & 1.49 & 1.50 & 0.93 & 1.12 & 0.87 \\
& SD & NA & 0.32 & 0.21 & 0.10 & 0.31 & 0.41 & 0.19 \\
\hline & & & & & & & &
\end{tabular}

\section{Wintertime advection of $\mathrm{Hg}$ from midlatitudes}

Several studies highlighted that the Arctic is significantly influenced by atmospheric pollution from midlatitudes - a phenomenon known as Arctic haze - during wintertime (Barrie et al., 1981; Heintzenberg et al., 1981; Shaw, 1982; Heidam et al., 1999, 2004; Bourgeois and Bey, 2011; Nguyen et al., 2013). Dastoor and Larocque (2004) used an online model to explain the observed seasonal variations in atmospheric mercury circulation and showed frequent episodes of mercury transport from midlatitudes sources to the Arctic in winter. Similarly, Hirdman et al. (2009) attributed the highest $10 \%$ of all wintertime $\mathrm{Hg}(0)$ data at NYA to transport of air masses especially from Europe. Higher $\mathrm{Hg}(0)$ concentrations in winter compared to fall at ALT, SND, and NYA can therefore be attributed to the meteorological differences in the seasonal circulation patterns (Dastoor and Larocque, 2004). Higher concentrations in winter at AND compared to the three other Arctic sites can be attributed to the powerful advection of air masses from Europe at this site (Durnford et al., 2010).

\section{Springtime AMDEs}

AMDEs in the Arctic are defined as $\mathrm{Hg}(0)$ concentrations below $1.00 \mathrm{ng} \mathrm{m}^{-3}$ (Steffen et al., 2005; Cobbett et al., 2007). Based on this threshold, AMDEs occur in $39,28,15$, and
$1 \%$ of the 2011-2014 springtime observations at ALT, SND, NYA, and AND, respectively. The fact that ALT experiences stronger and more frequent AMDEs than other Arctic sites could be due to air mass circulation patterns. Several studies indicated that a large fraction of the AMDEs reported at NYA and AND are suspected to result from the long-range transport of air masses containing depleted $\mathrm{Hg}(0)$ from areas over the Arctic Ocean (Gauchard et al., 2005; Sommar et al., 2007; Berg et al., 2008, 2013; Steen et al., 2011). A statistical analysis on the results from a Lagrangian particle dispersion model (FLEXPART) and $\mathrm{Hg}(0)$ concentrations measured at NYA was performed by Hirdman et al. (2009) to identify source regions of high- and low-Hg air masses. The authors concluded that the lowest $10 \%$ of the $\operatorname{Hg}(0)$ data at NYA in spring were strongly associated with transport across the seaice covered Arctic Ocean at low altitudes - areas where elevated $\mathrm{BrO}$ concentrations are seen in the atmospheric column by satellite observations (e.g., Lindberg et al., 2002). Similarly, a correlation of AMDEs with wind direction at ALT supports the origin of depletion events over the Arctic Ocean (Cole and Steffen, 2010). The less frequent and pronounced AMDEs at AND may be explained by the fact that this site is farther away from the source areas of AMDEs (Berg et al., 2008).

Over the 2011-2015 period, AMDEs at NYA are evenly distributed between April and May (38\% of the time in both 


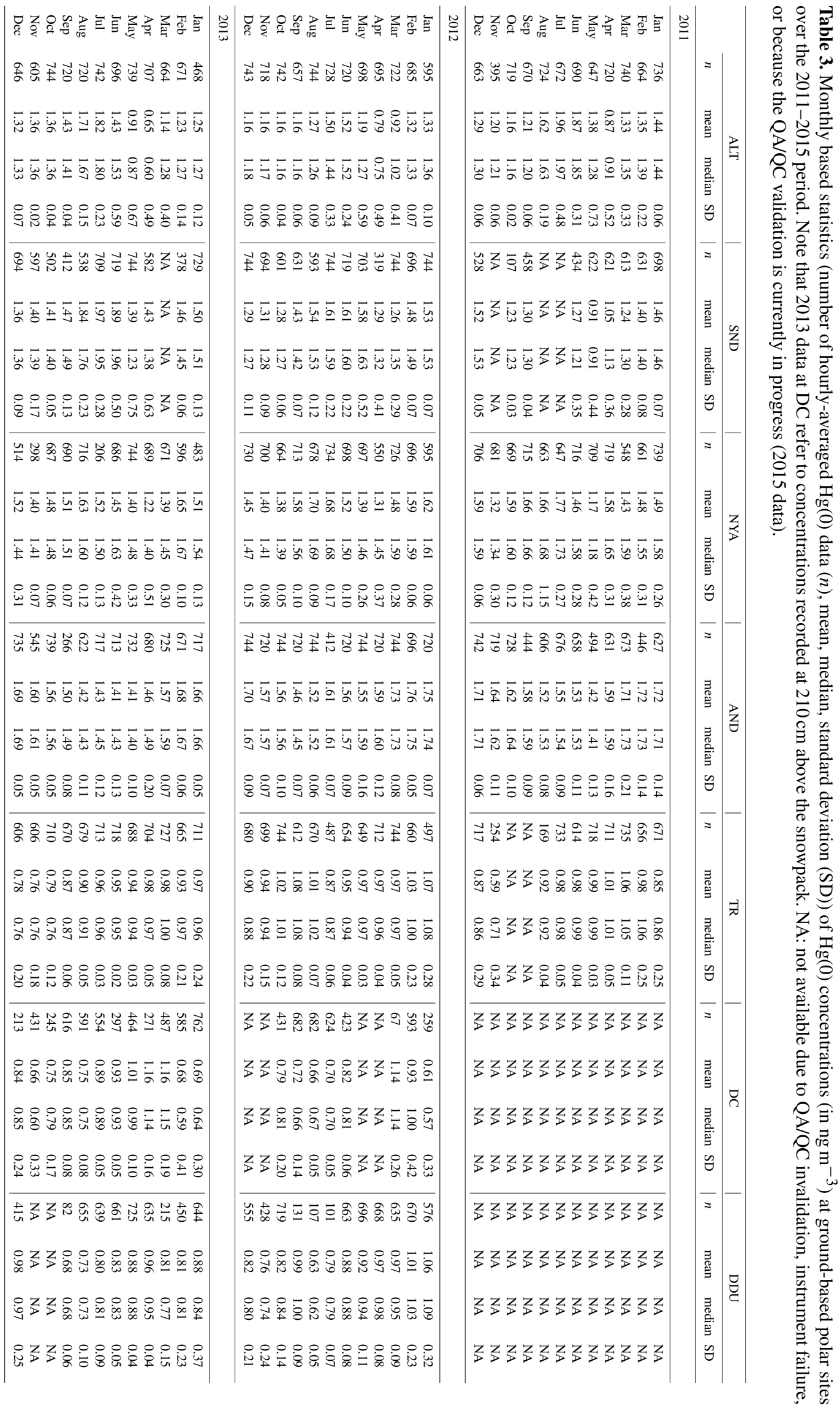




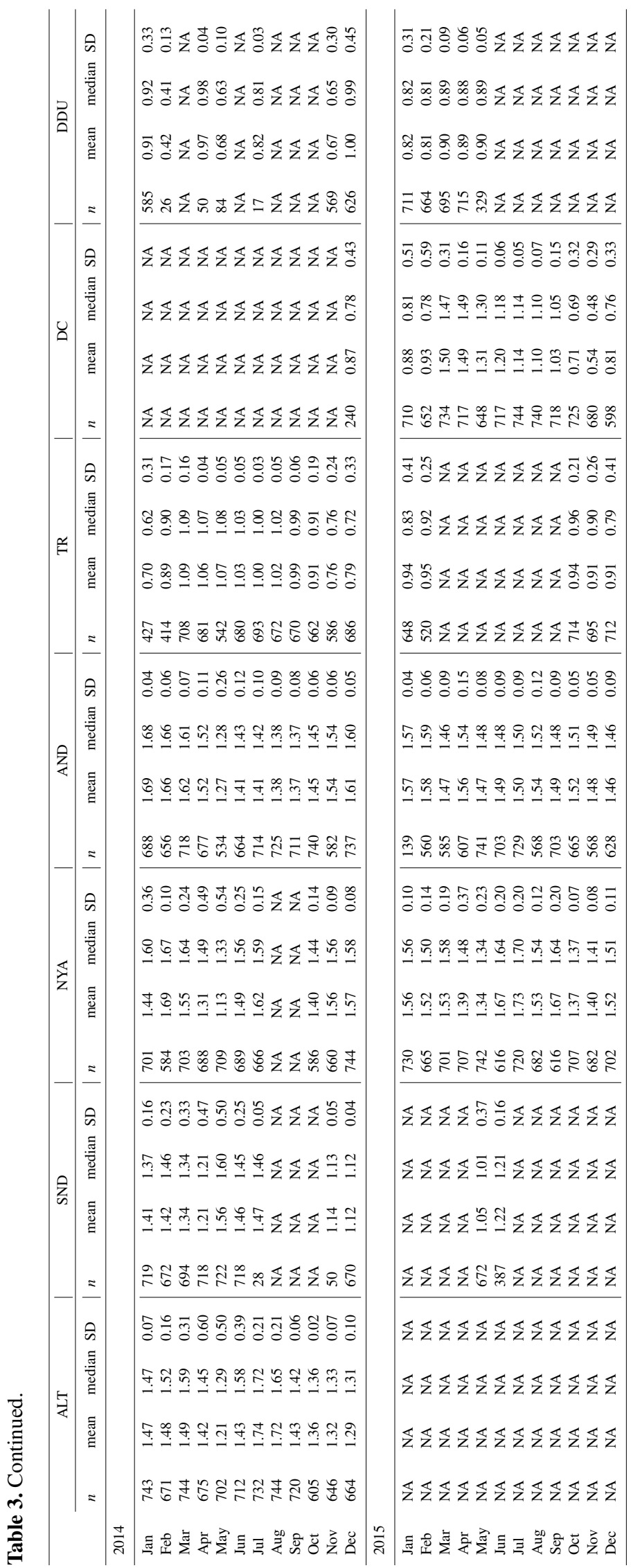



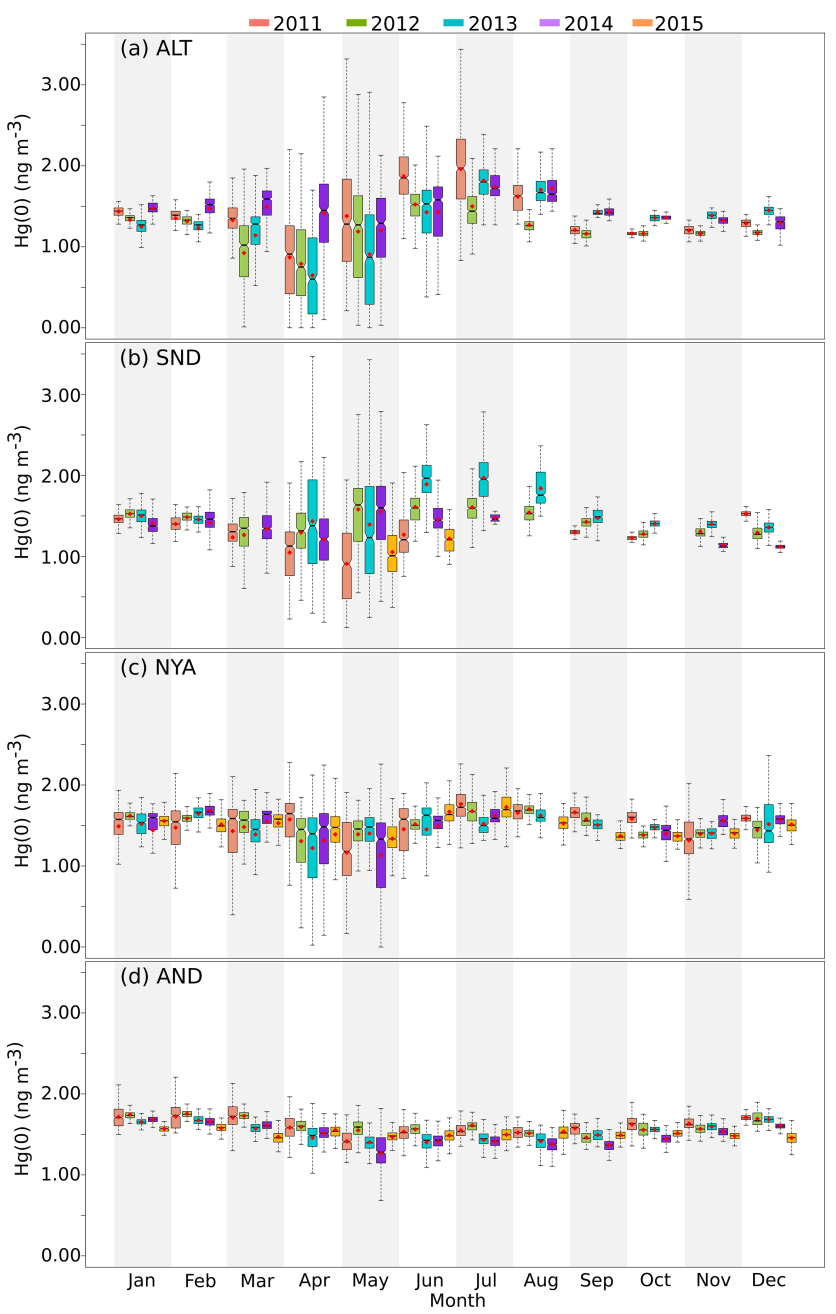

Figure 3. Box and whisker plots presenting the monthly $\mathrm{Hg}(0)$ concentration distribution at Arctic ground-based sites (a) ALT, (b) SND, (c) NYA, and (d) AND in 2011 (pink), 2012 (green), 2013 (turquoise), 2014 (purple), and 2015 (orange). Red diamond: mean. Bottom and top of the box: first and third quartiles. Band inside the box: median. Ends of the whiskers: lowest (highest) datum still within the 1.5 interquartile range of the lowest (upper) quartile. Outliers are not represented.

cases), with fewer in March and June (14 and $10 \%$ of the time, respectively). This result is in good agreement with the distribution reported by Berg et al. (2013) over the 20002009 period. Conversely, AMDEs are more frequent in April $(41 \%)$ than in May $(32 \%)$ at ALT, while less frequent in April (34\%) than in May (43\%) at SND. Interestingly, the analysis of the ALT dataset from 1995 to 2007 by Cole and Steffen (2010) revealed that, over time, the month of maximum AMDE activity shifted from May to April. In contrast, the analysis of the NYA dataset from 2000 to 2009 by Berg et al. (2013) did not evidence such a change in the timing of AMDEs. The reason for this shift in timing of AMDEs at ALT is not fully understood but could be due to local me-
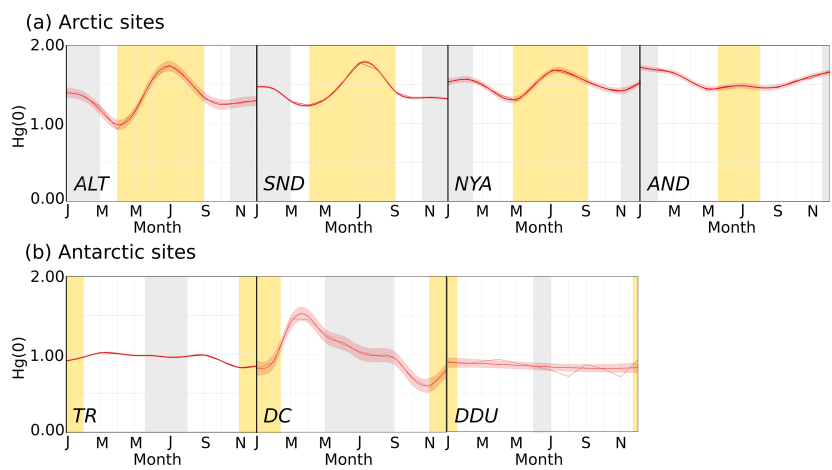

Figure 4. Seasonal variation (monthly mean along with the $95 \%$ confidence interval for the mean) of $\mathrm{Hg}(0)$ concentrations (in $\mathrm{ng} \mathrm{m}^{-3}$ ) at (a) Arctic and (b) Antarctic ground-based sites. Periods highlighted in yellow refer to $24 \mathrm{~h}$ sunlight and periods highlighted in gray to $24 \mathrm{~h}$ darkness. Summer refers to June-August (November-February), fall to September-November (March-April), winter to December-February (May-August), and spring to March-May (September-October) at Arctic (Antarctic) sites.

teorology (Cole and Steffen, 2010). The authors found that the length, magnitude, and frequency of AMDEs decreased with increasing local temperature. These results are consistent with earlier studies on the temperature dependence of the halogen chemistry initiating AMDEs and ozone depletion events (Koop et al., 2000; Adams et al., 2002; Tarasick and Bottenheim, 2002; Sander et al., 2006) and with a modeling study reporting that increasing surface air temperature decreases the frequency of AMDEs (Chen et al., 2015) . However, considering the fact that AMDEs observed at Arctic sites often result from the transport of depleted air masses, local temperature might not be the key explanatory parameter. Moore et al. (2014) showed that AMDEs and ozone depletion events near Barrow, Alaska, are directly linked to seaice dynamics. According to the authors, depletion events are favored by consolidated sea-ice cover but both $\mathrm{Hg}(0)$ and $\mathrm{O}_{3}$ concentrations immediately recover to near-background concentrations when air masses cross open leads within a day before measurements. The authors attributed this recovery of concentrations to changes in boundary layer dynamics induced by sea-ice leads, causing significant convective mixing with non-depleted air masses aloft. Further work is needed to establish the degree to which sea-ice dynamics across the Arctic might influence the interannual variability of AMDEs at the various Arctic sites. Indeed, AMDEs occurred at ALT in $36 \%$ (2011), $51 \%$ (2012), $50 \%$ (2013), and $21 \%$ (2014) of the springtime observations, at SND in $37 \%$ (2011), $16 \%$ (2012), $36 \%$ (2013), and $19 \%$ (2014) of the springtime observations, and finally at NYA in $18 \%$ (2011), $13 \%$ (2012), $16 \%$ (2013), $20 \%$ (2014), and $6 \%$ (2015) of the springtime observations.

Several studies reported RGM and $\mathrm{Hg}(\mathrm{p})$ concentrations during AMDEs at Arctic sites (Lindberg et al., 2002; Berg et 


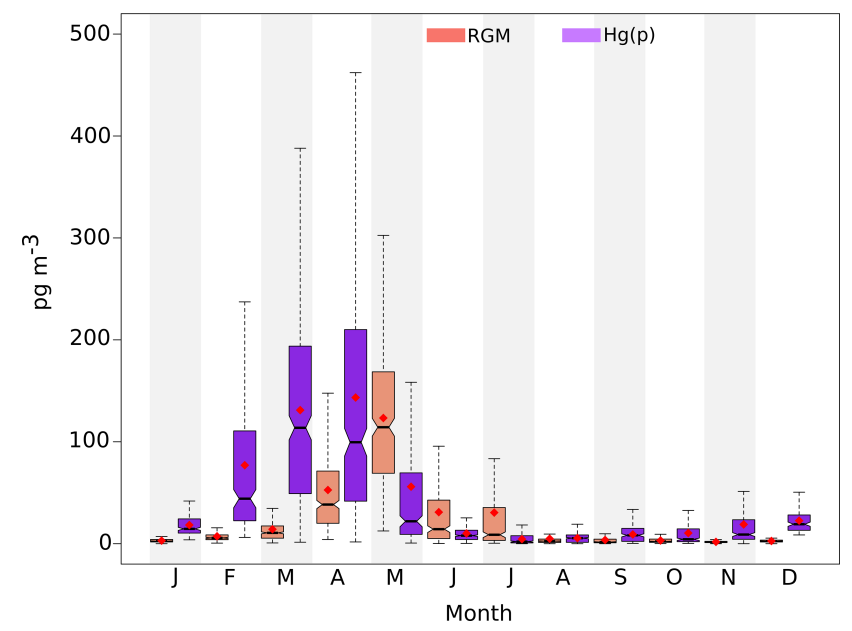

Figure 5. Box and whisker plots presenting the monthly RGM (in red) and $\mathrm{Hg}(\mathrm{p})$ (in violet) concentration distribution (in $\mathrm{pg} \mathrm{m}^{-3}$ ) at ALT over the 2011-2014 period. Red diamond: mean. Bottom and top of the box: first and third quartiles. Band inside the box: median. Ends of the whiskers: lowest (highest) datum still within the 1.5 interquartile range of the lowest (upper) quartile. Outliers are not represented.

al., 2003a; Steffen et al., 2003; Aspmo et al., 2005; Gauchard et al., 2005; Sprovieri et al., 2005a; Steen et al., 2011; Wang, 2015). Figure 5 shows box plots of the monthly concentrations of RGM and $\mathrm{Hg}(\mathrm{p})$ at ALT over the 2011-2014 period. A distinct annual cycle is highlighted in this figure. $\operatorname{Hg}(\mathrm{p})$ concentrations increase from November through February likely due to the Arctic haze (Steffen et al., 2014), reach a maximum in March and April due to AMDEs, and then decrease. RGM concentrations peak in spring and then gradually decrease. The production of RGM in June and July after the AMDEs season - is observed every year and remains unexplained (Steffen et al., 2014). While $\mathrm{Hg}(\mathrm{p})$ is the dominant species in early spring, a clear shift is observed, from the predominance of $\mathrm{Hg}(\mathrm{p})$ to RGM in AMDEs occurring toward the end of spring. This shift has already been evidenced at Churchill, Manitoba (Kirk et al., 2006), ALT (Cobbett et al., 2007), and NYA (Steen et al., 2011) and has been shown to repeat year after year at ALT (Steffen et al., 2014). Steffen et al. (2014) suggested that this shift is due to temperature and particle availability. Using a detailed air-snowpack model for interactions of bromine, ozone, and mercury in the springtime Arctic, Toyota et al. (2014) proposed that $\mathrm{Hg}(\mathrm{p})$ is mainly produced as $\mathrm{HgBr}_{4}^{2-}$ through uptake of RGM into bromine-enriched aerosols after ozone is significantly depleted in the air mass. In addition, Toyota et al. (2014) provided the temperature dependence of these reactions, which needs to be verified experimentally. Based on 10 years of data, Steffen et al. (2014) also reported higher levels of mercury in the snow when the atmospheric conditions favored the formation of RGM. This springtime shift from the predominance of $\mathrm{Hg}(\mathrm{p})$ to RGM in AMDEs likely directly impacts the amount of mercury deposited onto the snowpack. This will be further discussed in Sect. 3.1.2.

\section{Summer enhancement of $\mathrm{Hg}(0)$ concentrations}

According to Dastoor and Larocque (2004), advection of mercury from midlatitudes to the Arctic is insignificant in summer due to weak airflow movements and to a confined polar front. The increase of $\mathrm{Hg}(0)$ concentrations in summer could be due to the re-emission of mercury deposited during springtime AMDEs. However, the comparison of the magnitude of the springtime depletion and the magnitude of the summer enhancement at ALT suggests otherwise. Mean springtime $\mathrm{Hg}(0)$ concentrations are lower - suggesting more intense and/or frequent AMDEs - in $2012\left(0.97 \pm 0.53 \mathrm{ng} \mathrm{m}^{-3}\right)$ and 2013 $\left(0.89 \pm 0.57 \mathrm{ng} \mathrm{m}^{-3}\right)$ than in $2011\left(1.19 \pm 0.59 \mathrm{ng} \mathrm{m}^{-3}\right)$ and $2014\left(1.37 \pm 0.50 \mathrm{ng} \mathrm{m}^{-3}\right)$, while mean summertime concentrations are higher - suggesting more re-emission - in $2011\left(1.81 \pm 0.37 \mathrm{ng} \mathrm{m}^{-3}\right)$ and $2014\left(1.63 \pm 0.31 \mathrm{ng} \mathrm{m}^{-3}\right)$ than in $2012\left(1.43 \pm 0.27 \mathrm{ng} \mathrm{m}^{-3}\right)$ and $2013(1.65 \pm$ $0.41 \mathrm{ng} \mathrm{m}^{-3}$ ). Therefore, the summer enhancement of $\mathrm{Hg}(0)$ concentrations is generally attributed to emissions from snow and ice surfaces (Poulain et al., 2004; Sprovieri et al., 2005a, b, 2010; Douglas et al., 2012) and/or to evasion from the ice-free surface waters of the Arctic Ocean (Aspmo et al., 2006; Andersson et al., 2008; Hirdman et al., 2009; Fisher et al., 2013; Dastoor and Durnford, 2014; Yu et al., 2014; Soerensen et al., 2016). Inhomogeneous distributions of $\mathrm{Hg}(0)$ were observed over the Arctic Ocean during the CHINARE 2012 (Yu et al., 2014) and the Beringia 2005 (Sommar et al., 2010) expeditions. Both studies reported a rapid increase of concentrations in air when entering the ice-covered waters, highlighting the influence of sea-ice dynamics on $\mathrm{Hg}(0)$ concentrations. The atmospheric mercury model (GRAHM) used by Dastoor and Durnford (2014) simulated a first peak in $\mathrm{Hg}(0)$ concentrations driven by revolatilization from snowpack/meltwaters, followed by a second peak driven by oceanic evasion - the timing of the peaks varying with location and year. Additional field and modeling studies suggested that some of the mercury in surface ocean waters may come from riverine input (Fisher et al., 2012; Yu et al., 2014; Soerensen et al., 2016).

As can be seen in Fig. 3, $\mathrm{Hg}(0)$ concentrations are significantly higher ( $p$ value $<0.0001$, Mann-Whitney test) during summer 2011 at ALT $\left(1.81 \pm 0.37 \mathrm{ng} \mathrm{m}^{-3}\right)$ than during the following summers $\left(1.57 \pm 0.35 \mathrm{ng} \mathrm{m}^{-3}\right.$ on average). At $\mathrm{SND}, \mathrm{Hg}(0)$ concentrations peak in summer 2013 $\left(1.91 \pm 0.37 \mathrm{ng} \mathrm{m}^{-3}\right.$ vs. $1.52 \pm 0.26 \mathrm{ng} \mathrm{m}^{-3}$ on average during summers 2011, 2012, and 2014). One possible explanation for this interannual variability is sea-ice extent. Daily sea-ice maps can be obtained from http://www.iup. uni-bremen.de/iuppage/psa/2001/amsrop.html (Spreen et al., 2008). ALT and SND are both surrounded by multi-year ice. During summer 2011, the Hall Basin - waterway be- 
tween Greenland and Canada's northernmost island where ALT is located - was ice free. During summer 2013, seaice extent was particularly low in the Greenland Sea between Greenland and the Svalbard archipelago. These large areas of ice-free surface waters might have led to enhanced oceanic evasion near ALT and SND in 2011 and 2013, respectively. Indeed, Yu et al. (2014) reported a negative correlation between TGM and salinity over an Arctic ice-covered region, suggesting that ice melting would enhance TGM concentrations. This hypothesis is further supported by wind data obtainable from http://climate.weather. gc.ca/historical_data/search_historic_data_e.html and http: //villumresearchstation.dk/data/. At ALT, the summertime dominant wind direction is from the northeast but with frequent and strong winds from the south/southwest (Hall Basin), in line with results reported by Bilello (1973) and Cobbett et al. (2007). At SND, the dominant wind direction is from the southwest but the direction becomes more variable in summer with winds also occurring from south and east (Bilello, 1973; Nguyen et al., 2013). However, a comprehensive and systematic analysis of air mass back trajectories and sea-ice extent is required to further investigate parameters responsible for the observed interannual variability.

NYA is normally surrounded by open water in the summer. Therefore, oceanic emissions are expected to act as a significant local source to NYA, while being a regional and diffuse source at ALT and SND (Cole et al., 2013). However, the summer enhancement of $\operatorname{Hg}(0)$ concentrations is weaker at NYA than at ALT and SND (Fig. 4a). The western coast of Spitsbergen island, where NYA is located, was ice-free yearround over the period of interest, possibly preventing the buildup of mercury-enriched ice-covered surface waters in winter and intense evasion in summer. Additionally, a comparative study was carried out at NYA with measurements at both 12 and $474 \mathrm{~m}$ a.s.l. While Aspmo et al. (2005) found no significant difference between $\mathrm{Hg}(0)$ concentrations at the two elevations, several studies (Berg et al., 2003b; Sprovieri et al., 2005b; Sommar et al., 2007) reported that $\mathrm{Hg}(0)$ concentrations at $12 \mathrm{~m}$ a.s.l. were higher in magnitude and exhibited a higher variability than at $474 \mathrm{~m}$ a.s.l. Evidence of volatile mercury evasion from snow and water surfaces was also obtained, suggesting a cycling of mercury near the surface. Zeppelin station at $474 \mathrm{~m}$ a.s.l. is typically positioned over or at the top of the marine boundary layer of the fjord valley (Sommar et al., 2007) likely, at least partly, explaining why the summer enhancement of $\operatorname{Hg}(0)$ concentrations is weaker at NYA.

In contrast to observations at ALT, SND, and NYA, $\mathrm{Hg}(0)$ concentrations reach a minimum in summer at AND. Transport of air masses from Europe is dominant at AND (Durnford et al., 2010) and could mask any variability induced by oceanic evasion. The mean $\mathrm{Hg}(0)$ concentration in summer at AND (1.48 $\pm 0.12 \mathrm{ng} \mathrm{m}^{-3}$ over the 2011-2015 period) is consistent with the value of $\sim 1.42 \mathrm{ng} \mathrm{m}^{-3}$ reported at Pallas, Finland, over the 2013-2014 period (Sprovieri et al., 2016b).

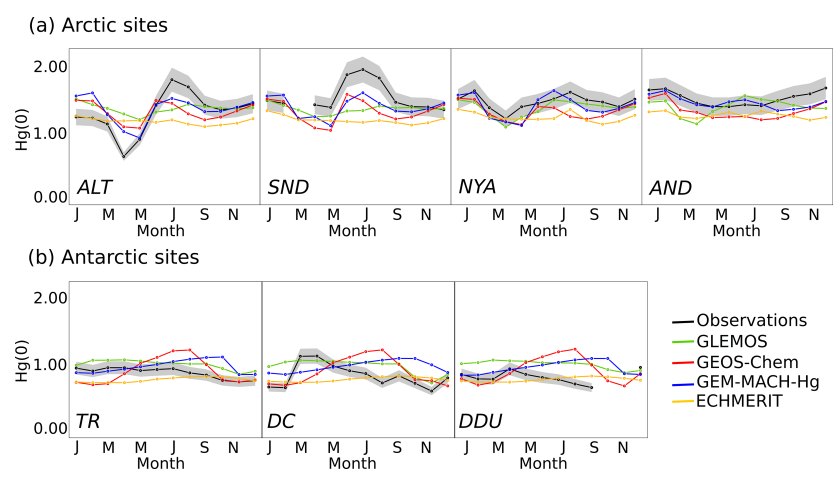

Figure 6. Year 2013 monthly-averaged $\mathrm{Hg}(0)$ concentrations (in $\mathrm{ng} \mathrm{m}^{-3}$ ) at (a) Arctic and (b) Antarctic ground-based sites: observations (in black) and concentrations according to the four global models (GLEMOS in green, GEOS-Chem in red, GEM-MACH-Hg in blue, ECHMERIT in yellow). The gray shaded regions indicate a $10 \%$ uncertainty for observations.

\subsubsection{Comparison with models}

Table 4 displays goodness-of-fit statistics between monthlyaveraged modeled and observed data in 2013. Except at ALT, modeled $\mathrm{Hg}(0)$ concentrations are biased low, suggesting that the four global models tend to underestimate sources of $\mathrm{Hg}(0)$. The ability of the four models to reproduce the observed seasonality of $\mathrm{Hg}(0)$ concentrations at Arctic sites in 2013 is shown in Fig. 6a and discussed in the following sections. As mentioned in Sect. 2.2, GEM-MACH-Hg and GEOS-Chem provided hourly-averaged data from 2011 to 2014. The interannual variability of the monthly $\mathrm{Hg}(0)$ concentration distribution at Arctic sites as simulated by the two models is displayed in Fig. 7a while Table 5 shows the percent bias between hourly-averaged modeled and observed data on a seasonal basis from 2011 to 2014 .

\section{Seasonal variation}

\section{(a) Winter}

All the models (except ECHMERIT) overestimate $\mathrm{Hg}(0)$ concentrations at ALT in January and February 2013 but reproduce well the average value in December 2013 (Fig. 6a). It is worth noting that the observed mean value in January/February $2013\left(1.24 \pm 0.13 \mathrm{ng} \mathrm{m}^{-3}\right)$ is lower than the value observed in December $2013\left(1.45 \pm 0.07 \mathrm{ng} \mathrm{m}^{-3}\right)$ and lower than the hemispheric background (1.30-1.60 $\mathrm{ng} \mathrm{m}^{-3}$ according to Sprovieri et al., 2016b). Additionally, the observed mean value in January/February 2013 is at the low end of values reported at this period of the year at ALT from 2011 to 2014 (Fig. 3, $1.40 \pm 0.16 \mathrm{ng} \mathrm{m}^{-3}$ in $2011,1.32 \pm 0.09 \mathrm{ng} \mathrm{m}^{-3}$ in 2012 , and $1.47 \pm 0.12 \mathrm{ng} \mathrm{m}^{-3}$ in 2014). The interannual variability of observed $\mathrm{Hg}(0)$ concentrations at ALT is not captured by models. Modeled $\mathrm{Hg}(0)$ concentrations in January/February range from $1.48 \pm 0.03$ 
Table 4. Goodness-of-fit statistics between monthly-averaged (year 2013) modeled and observed $\mathrm{Hg}(0)$ data at all ground-based sites: NashSutcliffe efficiency (NSE, quantity without unit), root mean square error (RMSE, in $\mathrm{ng} \mathrm{m}^{-3}$ ), and percent bias (PBIAS, in \%).

\begin{tabular}{llllllll}
\hline & ALT & SND & NYA & AND & TR & DC & DDU \\
\hline GLEMOS & & & & & & & \\
\hline NSE & 0.12 & -0.83 & 0.00 & -2.76 & -1.83 & -0.28 & -6.10 \\
RMSE & 0.29 & 0.29 & 0.11 & 0.20 & 0.13 & 0.19 & 0.24 \\
PBIAS & 4.9 & -12.0 & -6.3 & -8.3 & 14.0 & 16.2 & 25.4 \\
\hline GEOS-Chem & & & & & & & \\
\hline NSE & 0.32 & -0.85 & -1.82 & -2.50 & -4.76 & -1.07 & -8.15 \\
RMSE & 0.25 & 0.29 & 0.18 & 0.19 & 0.19 & 0.25 & 0.27 \\
PBIAS & 1.3 & -13.7 & -9.7 & -12.2 & 3.0 & 7.5 & 16.9 \\
\hline GEM-MACH-Hg & & & & & & & \\
\hline NSE & 0.49 & -0.17 & -0.40 & -0.26 & -2.98 & -1.08 & -4.87 \\
RMSE & 0.22 & 0.23 & 0.13 & 0.12 & 0.16 & 0.25 & 0.22 \\
PBIAS & 4.1 & -9.0 & -4.4 & -4.1 & 10.2 & 16.3 & 16.7 \\
\hline ECHMERIT & & & & & & & \\
\hline NSE & -0.27 & -2.85 & -4.16 & -6.24 & -2.50 & -0.32 & -0.85 \\
RMSE & 0.34 & 0.42 & 0.25 & 0.28 & 0.15 & 0.20 & 0.12 \\
PBIAS & -10.0 & -22.7 & -15.5 & -16.7 & -11.8 & -6.6 & -5.1 \\
\hline
\end{tabular}

(a) Arctic sites

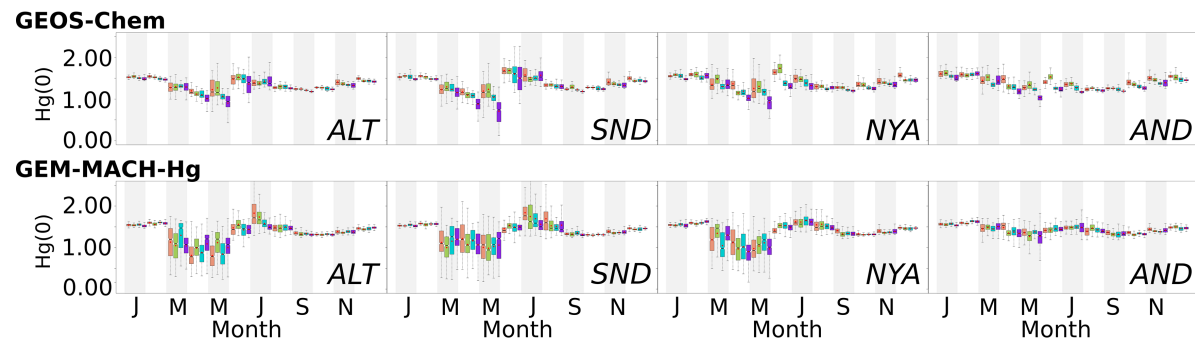

(b) Antarctic sites

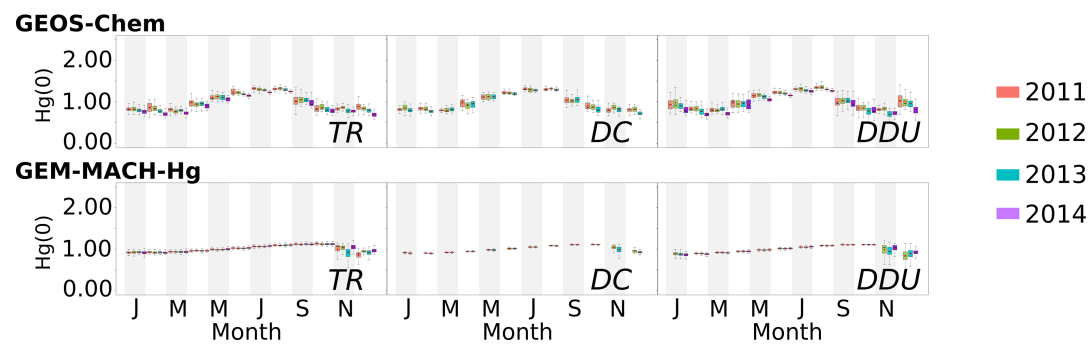

Figure 7. Box and whisker plots presenting the monthly $\mathrm{Hg}(0)$ concentration distribution at (a) Arctic and (b) Antarctic ground-based sites as simulated by GEOS-Chem and GEM-MACH-Hg in 2011 (pink), 2012 (green), 2013 (turquoise), and 2014 (purple). Red diamond: mean. Bottom and top of the box: first and third quartiles. Band inside the box: median. Ends of the whiskers: lowest (highest) datum still within the 1.5 interquartile range of the lowest (upper) quartile. Outliers are not represented.

in 2014 to $1.54 \pm 0.03 \mathrm{ng} \mathrm{m}^{-3}$ in 2011 and 2012 with GEOSChem and from $1.54 \pm 0.06$ in 2012 to $1.58 \pm 0.04 \mathrm{ng} \mathrm{m}^{-3}$ in 2013 with GEM-MACH-Hg. Similarly, the interannual variability of modeled $\mathrm{Hg}(0)$ concentrations is low at other Arctic sites (Fig. 7a). The wintertime interannual variability of observed $\mathrm{Hg}(0)$ concentrations might be driven by meteo- rology and mercury emissions in midlatitudes. However, the AMAP/UNEP (2010) global inventory of mercury anthropogenic emissions (annual mean emission fields) was used for all simulated years (2011-2014) in both GEOS-Chem and GEM-MACH-Hg, preventing the consideration of interannual changes in anthropogenic emissions. 
Table 5. Percent bias (in \%) between hourly-averaged modeled and observed $\mathrm{Hg}(0)$ data at all ground-based sites. Summer refers to JuneAugust (November-February), fall to September-November (March-April), winter to December-February (May-August), and spring to March-May (September-October) at Arctic (Antarctic) sites. NA: not available due to QA/QC invalidation or instrument failure.

\begin{tabular}{|c|c|c|c|c|c|c|c|c|}
\hline & \multicolumn{4}{|c|}{ GEOS-Chem } & \multicolumn{4}{|c|}{ GEM-MACH-Hg } \\
\hline & 2011 & 2012 & 2013 & 2014 & 2011 & 2012 & 2013 & 2014 \\
\hline \multicolumn{9}{|c|}{ Summer } \\
\hline ALT & -23.9 & -1.9 & -15.4 & -17.1 & -12.3 & 11.1 & -9.2 & -10.0 \\
\hline SND & 34.3 & -3.8 & -22.0 & 4.6 & 11.6 & 1.4 & -17.5 & 3.4 \\
\hline NYA & -8.9 & -7.3 & -14.7 & -15.6 & -5.9 & -4.4 & -0.2 & -1.0 \\
\hline AND & -13.2 & -10.4 & -11.9 & -14.1 & -7.2 & -6.8 & 3.2 & 3.0 \\
\hline TR & -1.1 & -14.0 & -8.9 & -5.6 & 4.0 & -1.9 & 6.3 & 23.6 \\
\hline DC & NA & 1.7 & 15.6 & NA & NA & 8.7 & 35.6 & NA \\
\hline DDU & NA & 0.1 & 0.0 & -8.3 & NA & -3.4 & -1.7 & 8.4 \\
\hline \multicolumn{9}{|l|}{ Fall } \\
\hline ALT & 9.4 & 11.7 & -9.8 & -9.5 & 13.4 & 14.7 & -3.6 & -3.0 \\
\hline SND & -3.3 & -1.5 & -9.1 & 23.4 & 2.7 & -0.5 & -5.0 & 26.8 \\
\hline NYA & -11.1 & -7.9 & -14.4 & -12.0 & -9.3 & -8.4 & -9.7 & -8.5 \\
\hline AND & -12.6 & -11.1 & -15.0 & -12.1 & -13.4 & -12.5 & -13.9 & -6.5 \\
\hline $\mathrm{TR}$ & -13.1 & -12.0 & -10.9 & -24.6 & -7.8 & -1.4 & -2.9 & -11.6 \\
\hline DC & NA & -31.5 & -22.6 & NA & NA & -18.6 & -43.4 & NA \\
\hline DDU & NA & -9.6 & 1.1 & -19.9 & NA & -3.2 & 2.1 & -4.4 \\
\hline \multicolumn{9}{|l|}{ Winter } \\
\hline ALT & 11.8 & 18.5 & 11.7 & 3.3 & 12.8 & 19.2 & 16.2 & 8.0 \\
\hline SND & 5.5 & 5.5 & 4.2 & 11.6 & 5.1 & 4.8 & 5.5 & 15.3 \\
\hline NYA & 4.1 & 0.1 & -3.0 & -4.0 & 1.3 & -1.4 & -1.4 & -1.5 \\
\hline AND & -7.6 & -9.0 & -8.0 & -7.6 & -10.1 & -11.1 & -7.2 & -6.7 \\
\hline $\mathrm{TR}$ & 25.3 & 29.8 & 29.6 & 14.1 & 5.8 & 9.2 & 11.3 & 2.8 \\
\hline DC & NA & 79.9 & 39.3 & NA & NA & 48.4 & 17.8 & NA \\
\hline DDU & NA & 38.5 & 50.4 & 49.4 & NA & 15.4 & 26.9 & 40.4 \\
\hline \multicolumn{9}{|l|}{ Spring } \\
\hline ALT & 3.2 & 27.4 & 29.7 & -21.8 & -23.0 & 9.3 & 11.8 & -24.0 \\
\hline SND & 12.3 & -11.6 & -25.5 & -33.3 & 4.2 & -27.7 & -23.0 & -18.8 \\
\hline NYA & -5.8 & -5.3 & -9.7 & -17.8 & -23.8 & -17.0 & -21.5 & -20.4 \\
\hline AND & -11.5 & -13.8 & -12.4 & -16.7 & -9.3 & -16.0 & -5.5 & -7.6 \\
\hline TR & NA & -9.0 & 13.0 & -7.7 & NA & 7.5 & 36.5 & 18.1 \\
\hline DC & NA & 32.6 & 22.9 & NA & NA & 48.8 & 34.5 & NA \\
\hline DDU & NA & 3.2 & 73.6 & NA & NA & 31.9 & 62.8 & NA \\
\hline
\end{tabular}

\section{(b) Spring}

Springtime reflects the lowest $\mathrm{Hg}(0)$ concentrations at ALT, SND, and NYA due to the occurrence of AMDEs (see Sect. 3.1.1). This minimum is well reproduced by GEMMACH-Hg, GEOS-Chem, and GLEMOS at all three stations but not reproduced by ECHMERIT (Fig. 6a). It should be noted that there is no parameterization of AMDEs in the latter. Interestingly, GLEMOS predicts a similar springtime minimum at AND in contradiction with the seasonal pattern observed at this station (see Sect. 3.1.1). This discrepancy can likely be attributed to uncertainties in Br fields extracted from p-TOMCAT.
As discussed in Sect. 3.1.1, AMDEs were less frequent at ALT in 2014. This lower occurrence frequency is fairly well reproduced by GEM-MACH-Hg (61\% (2011), $43 \%$ (2012), $53 \%$ (2013), and 36\% (2014)) but not at all by GEOS-Chem (4\% (2011), $6 \%$ (2012), $13 \%$ (2013), and $37 \%$ (2014)). A temperature dependence of $\mathrm{BrO}$ concentrations is implemented in GEM-MACH-Hg and $\mathrm{Br}_{2}$ is assumed to occur only over consolidated sea ice, which would change with changing meteorological conditions. Conversely, a constant value of 5 pptv of $\mathrm{BrO}$ is added in the springtime Arctic boundary layer into GEOS-Chem v9-02. However, updates to Arctic mercury processes will be implemented in v11-01 based on Fisher et al. (2012) and Fisher 
et al. (2013) (http://wiki.seas.harvard.edu/geos-chem/index. php/Mercury\#Updates_to_Arctic_Hg_processes). BrO concentrations will depend on temperature according to a relationship chosen to optimize spring $\mathrm{Hg}(0)$ concentrations and the shift of peak depletion at ALT from May to April (see Sect. 3.1.1). It should also be noted that GEOS-Chem relies on GEOS-5 and GEOS-FP meteorological fields in 20112013 and 2014, respectively. Simulations in polar regions can be very sensitive to subtle changes in meteorological fields, especially during the AMDEs season, which could at least partly explain the interannual variability of modeled AMDEs occurrence frequencies.

Based on the work by Moore et al. (2014) showing the impact of sea-ice leads on AMDEs (AMDEs might be favored by consolidated sea-ice cover; see Sect. 3.1.1), real-time distribution of sea-ice dynamics including presence of leads is needed. Contrarily to conclusions by Moore et al. (2014), a recent modeling study (Chen et al., 2015) carried out using GEOS-Chem v9-02 - but including an ice/snow module and riverine inputs as described by Fisher et al. (2012) and Fisher et al. (2013) - showed that increasing sea-ice lead occurrence increases the frequency of AMDEs. These contradictory results highlight the fact that further work is needed regarding the degree to which sea-ice dynamics across the Arctic alters mercury chemistry in spring.

\section{(c) Summer}

All the models (except ECHMERIT in which polar processes are not implemented) capture, to some extent, the summertime $\mathrm{Hg}(0)$ enhancement. GLEMOS clearly underestimates summertime mean concentrations at ALT and SND (Fig. 6a). This can be attributed to missing re-emissions and/or oceanic evasion. As mentioned is Sect. 3.1.1, Dastoor and Durnford (2014) suggested two distinct summertime maxima: the first one supported by revolatilization from snowpack/meltwaters occurring from the end of May to mid-June at ALT and in June at NYA; the second one supported by oceanic evasion from mid-July to early August at ALT and NYA. GEOSChem gives a summer maximum in June instead of July at ALT, SND, and NYA. This time lag might result from to the fact that oceanic evasion from the Arctic Ocean is not implemented in v9-02. v11-01 of the model will include, among other updates, new present-day (2009) fields for net primary productivity (NPP) based on Jin et al. (2012), a UV-B dependence for $\mathrm{Hg}$ (II) reduction in seawater based on results of O'Driscoll et al. (2006), updated $\mathrm{Hg}(0)$ emissions from snow, and a source of mercury from the snowpack to the Arctic Ocean at the onset of snowmelt. In order for the models to reproduce the interannual variability of $\mathrm{Hg}(0)$ concentrations, real-time distribution of areas of ice-free surface waters along with the type of surface (ice/snow/snow-free bedrock) are needed.
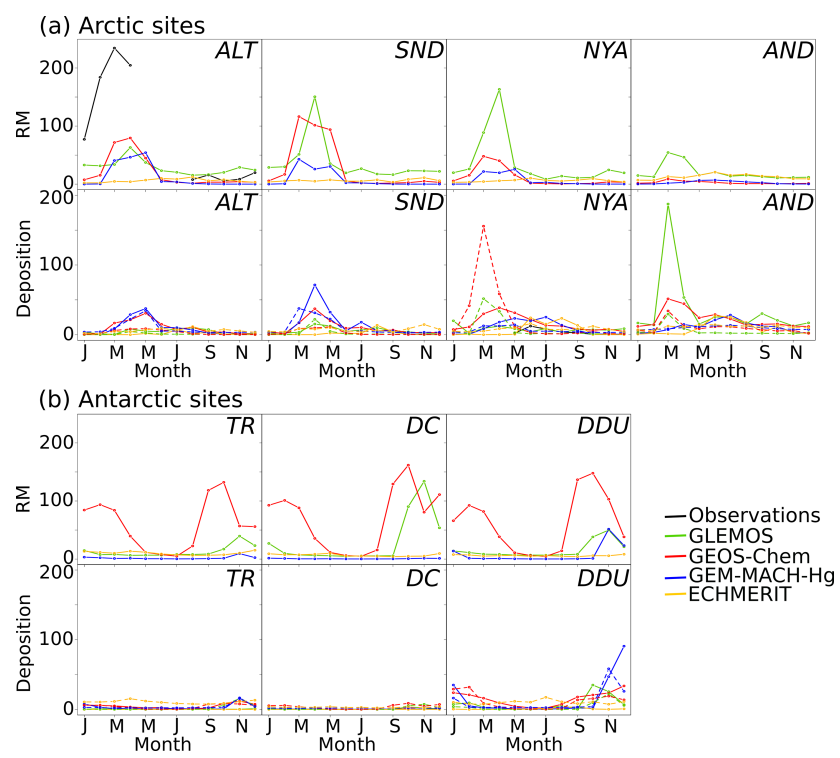

Figure 8. Year 2013 monthly-averaged mean reactive mercury (RM) concentrations (in $\mathrm{pg} \mathrm{m}^{-3}$ ) along with mean wet (solid line) and dry (dashed line) deposition (in $\mathrm{ng} \mathrm{m}^{-2}$ day $^{-1}$ ) at (a) Arctic and (b) Antarctic ground-based sites: observations (in black) and concentrations according to the four global models (GLEMOS in green, GEOS-Chem in red, GEM-MACH-Hg in blue, ECHMERIT in yellow). Note that RM (wet deposition) observations are available at ALT (NYA) only.

\section{Reactive mercury and deposition}

Year 2013 modeled monthly-averaged RM concentrations and wet/dry deposition are displayed in Fig. 8a. GEOSChem, GEM-MACH-Hg, and GLEMOS predict increased RM concentrations in spring, during the AMDEs season, consistent with the observed pattern at ALT (Fig. 5) and NYA (Wang, 2015). The fact that ECHMERIT does not capture the spring enhancement is not surprising since the model does not implement any chemistry specific to polar regions. GLEMOS also predicts a RM spring maximum at AND, in line with the modeled $\mathrm{Hg}(0)$ spring minimum at this site (Fig. 6a). As discussed in a previous section, this can likely be attributed to uncertainties in $\mathrm{Br}$ fields extracted from $\mathrm{p}$ TOMCAT. Long-term measurements of RM in the Arctic are scarce and limited to ALT and NYA (data not presented here). According to Fig. 8a, all four models underestimate RM concentrations at ALT from at least January to April 2013. Similarly, the comparison of modeled RM concentrations at NYA with annual averages reported by Steen et al. (2011) and Wang (2015) suggests an underestimation of the concentrations by GEOS-Chem, GEM-MACH-Hg, and ECHMERIT.

According to the models, deposition of mercury peaks in spring at ALT and SND, consistent with the RM spring maximum. The deposition of mercury during AMDEs depends on temperature, relative humidity, and aerosol contribution 
(Cobbett et al., 2007) and is higher when the atmospheric conditions favor the formation of RGM over $\mathrm{Hg}(\mathrm{p}$ ) (see Sect. 3.1.1). Therefore, as suggested by Steffen et al. (2015), prevailing atmospheric conditions must be fully characterized in order to accurately evaluate the deposition of mercury. GEOS-Chem and GLEMOS both predict higher dry deposition in spring at NYA. Wet deposition is largely driven by precipitation - RM being readily scavenged by rain or snow, whereas dry deposition depends on the boundary layer stability and the type of the underlying surface (Cadle, 1991). Deposition of mercury in the Arctic is typically inferred from concentrations of total mercury in the snowpack (e.g., Steffen et al., 2014) or from a $\mathrm{Hg}(0)$ flux gradient method (Steffen et al., 2002; Brooks et al., 2006; Cobbett et al., 2007; Steen et al., 2009) and not through direct measurement of wet and dry deposition, making it difficult to evaluate the accuracy of models predictions. To the best of our knowledge, NYA is the only site out of the four Arctic sites where wet deposition measurements have been reported (Sprovieri et al., 2016a). From May to December 2013, the observed net wet deposition flux is equal to $0.9 \mu \mathrm{g} \mathrm{m}^{-2}$ while modeled fluxes amount to $1.7,3.2,2.8$, and $2.4 \mathrm{\mu g} \mathrm{m}^{-2}$ according to GLEMOS, GEOS-Chem, GEM-MACH-Hg, and ECHMERIT, respectively. All four models overestimate the wet deposition flux. Interestingly, all four models also overestimate the amount of precipitation (by a factor of 2.0, 2.2, 2.1, and 1.1, respectively; data not shown). Several studies showed that the form of precipitation (rain vs. snow) influences the collection efficiency of the sampler. Lynch et al. (2003) and Prestbo and Gay (2009) found that the annual collection efficiency is $89 \%$ and $87.1 \pm 6.5 \%$, respectively, at cold weather sites in the United States and Canada experiencing snowfall in winter vs. $98.8 \pm 4.3 \%$ at warm weather sites (Prestbo and Gay, 2009). Assuming an annual $89 \%$ collection efficiency of snow at NYA does not narrow the gap between observed and modeled amounts of precipitation. However, an annual $89 \%$ collection efficiency at NYA seems generous considering that snow falls year-round and that strong wind $\left(>10 \mathrm{~m} \mathrm{~s}^{-1}\right)$ and blowing snow are frequent, especially in winter (Maturilli et al., 2013).

\subsection{Antarctic sites}

\subsubsection{Observations}

Figure $2 \mathrm{~b}$ shows monthly box plots of all data collected in Antarctica (ground-based sites and cruises). $\mathrm{Hg}(0)$ concentrations from the ANT cruises displayed in Fig. 2b refer to data collected when R/V Polarstern operated within the marginal sea-ice region (from 8 to 23 July 2013, from 25 July to 9 August 2013, and from 28 August to 5 October 2013) (Nerentorp Mastromonaco et al., 2016). Similarly, $\operatorname{Hg}(0)$ concentrations from the OSO cruise refer to data collected at latitude $>60^{\circ} \mathrm{S}$. $\mathrm{Hg}(0)$ concentrations measured during the ANT and OSO cruises are somewhat higher than values at ground-based Antarctic sites. The average value at Antarctic sites is $0.96 \pm 0.32 \mathrm{ng} \mathrm{m}^{-3}$, i.e., $35 \%$ lower than the average value at Arctic sites (see Sect. 3.1). This result is consistent with the north-to-south $\mathrm{Hg}(0)$ decreasing gradient reported by Sprovieri et al. (2016b) and with values reported at southern hemispheric midlatitudes sites (Angot et al., 2014; Slemr et al., 2015).

The $\mathrm{Hg}(0)$ concentration data from the three Antarctic ground-based sites for the period 2011-2015 are presented as monthly box and whisker plots in Fig. 9. Information regarding annually and monthly based statistics at the three sites can be found in Tables 2 and 3, respectively. The annual medians for 2011-2015 at TR and 2012-2015 at DDU (Table 2) suggest a low interannual variability in the distribution of $\mathrm{Hg}(0)$ concentrations. Conversely, $\operatorname{Hg}(0)$ concentrations are notably higher in 2015 than in 2012 and 2013 at DC. This trend is more apparent from Fig. 9b, especially from March to September. It is worth noting that in 2015 measurements were performed at a different location within the "clean area" (the instrument was moved from one shelter to another). Additionally, following the January 2014 instrument failure, a new Tekran instrument operated in 2015. The combination of these two elements likely, at least partly, explains the offset observed in 2015. Despite this offset, the seasonal trends of $\mathrm{Hg}(0)$ repeat from year to year at DC (see below).

The mean seasonal variation of $\operatorname{Hg}(0)$ concentrations at Antarctic ground-based sites is displayed in Fig. 4b. Summer refers to November-February, fall to March-April, winter to May-August, and spring to September-October. At TR, the $\operatorname{Hg}(0)$ concentrations are significantly ( $p$ value $<0.0001$, Mann-Whitney test) higher in winter $\left(0.98 \pm 0.06 \mathrm{ng} \mathrm{m}^{-3}\right)$ than in summer $\left(0.89 \pm 0.29 \mathrm{ng} \mathrm{m}^{-3}\right)$, in good agreement with the seasonal variation reported at TR by Pfaffhuber et al. (2012) from February 2007 to June 2011, and at Neumayer (NM) by Ebinghaus et al. (2002). Contrarily, $\mathrm{Hg}(0)$ concentrations at DDU are slightly but significantly ( $p$ value $<0.0001$, Mann-Whitney test) higher in summer $\left(0.88 \pm 0.32 \mathrm{ng} \mathrm{m}^{-3}\right)$ than in winter $\left(0.84 \pm 0.11 \mathrm{ng} \mathrm{m}^{-3}\right)$. On the high-altitude Antarctic Plateau at $\mathrm{DC}, \mathrm{Hg}(0)$ concentrations exhibit a distinct maximum in fall $\left(1.45 \pm 0.27 \mathrm{ng} \mathrm{m}^{-3}\right)$ and a minimum in summer $\left(0.78 \pm 0.46 \mathrm{ng} \mathrm{m}^{-3}\right)$. The mechanisms which cause the seasonal variation of $\mathrm{Hg}(0)$ concentrations at Antarctic sites are discussed in the following sections.

\section{The winter mysteries}

$\mathrm{Hg}(0)$ concentrations at TR remain at a fairly constant level of $0.98 \pm 0.06 \mathrm{ng} \mathrm{m}^{-3}$ on average from April to $\mathrm{Au}-$ gust (Fig. 2b). This result is in good agreement with observations at Neumayer (Ebinghaus et al., 2002). Pfaffhuber et al. (2012) attributed this phenomenon to the lack of photochemical oxidation processes during the polar night. Conversely, $\mathrm{Hg}(0)$ concentrations exhibit a gradual $30 \%$ decrease at DC from $1.48 \pm 0.19$ on average in April to 

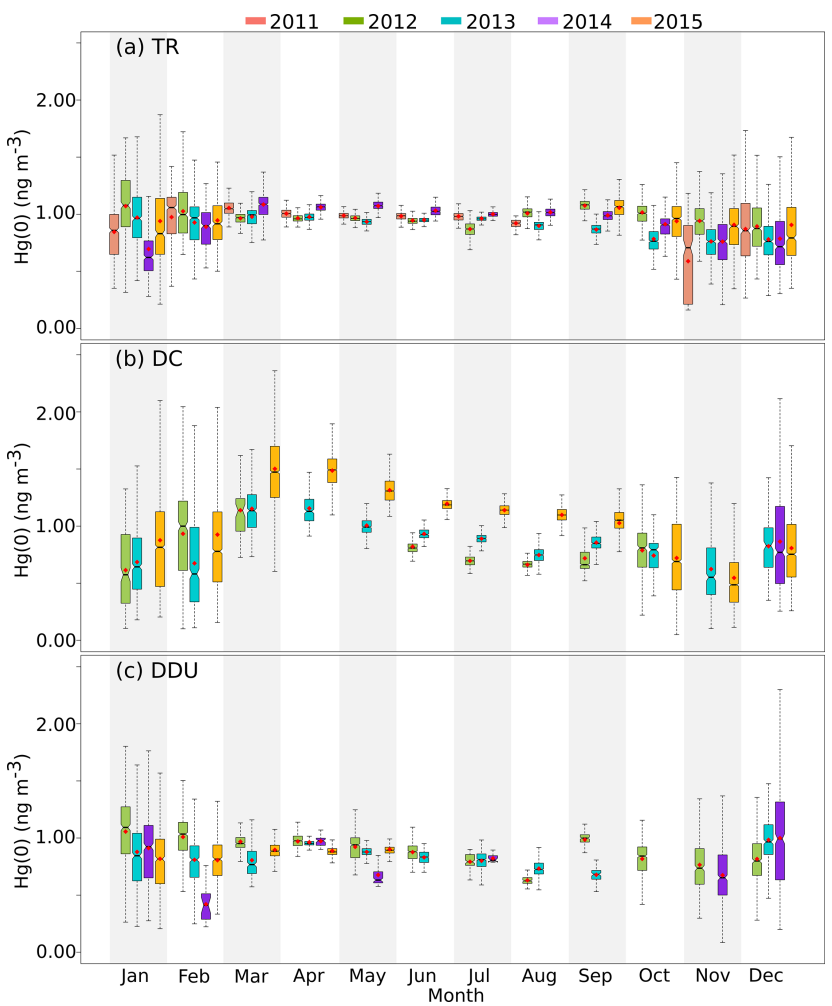

Figure 9. Box and whisker plots presenting the monthly $\mathrm{Hg}(0)$ concentration distribution at ground-based Antarctic sites (a) TR, (b) DC, and (c) DDU in 2011 (pink), 2012 (green), 2013 (turquoise), 2014 (purple), and 2015 (orange). Red diamond: mean. Bottom and top of the box: first and third quartiles. Band inside the box: median. Ends of the whiskers: lowest (highest) datum still within the 1.5 interquartile range of the lowest (upper) quartile. Outliers are not represented.

$0.98 \pm 0.20 \mathrm{ng} \mathrm{m}^{-3}$ in August. This decreasing trend remains unexplained and possibly results from the dry deposition of $\mathrm{Hg}(0)$ onto the snowpack (Angot et al., 2016b). In 2013, measurements were performed at various height levels above the snow surface. Interestingly, Angot et al. (2016b) reported a steeper decrease of $\operatorname{Hg}(0)$ concentrations close to the snow surface, suggesting that the snowpack may act as a sink for mercury. Similarly, a gradual $20 \%$ decrease in $\mathrm{Hg}(0)$ concentrations is observed at DDU, from $0.94 \pm 0.07$ on average in April to $0.72 \pm 0.10 \mathrm{ng} \mathrm{m}^{-3}$ in August (Fig. 2b). Based on an analysis of air mass back trajectories, Angot et al. (2016a) suggested that this decreasing trend at DDU most likely results from reactions occurring within the shallow boundary layer on the Antarctic Plateau, subsequently transported toward the coastal margins by katabatic winds. DDU is influenced most of the time by inland air masses whereas several studies showed that stations such as NM are not significantly impacted by air masses originating from the Antarctic Plateau (Helmig et al., 2007; Legrand et al., 2016b), explaining why concentrations remain rather stable at NM and TR throughout winter.
$\mathrm{Hg}(0)$ concentration exhibits abrupt increases when moist and warm air masses from lower latitudes occasionally reach the three ground-based Antarctic stations. At DDU, such events are concomitant with an enhanced fraction of oceanic air masses reaching the site according to the HYSPLIT model simulations, and with increased sodium concentrations (Angot et al., 2016a). At DC, these advections of warm and moist air masses are confirmed by an increase of temperature at $10 \mathrm{~m}$ a.g.l. and a high integrated water vapor column (Angot et al., 2016b). Finally, based on a statistical analysis of source and sink regions, Pfaffhuber et al. (2012) showed that transport from lower-latitude regions is frequently associated with the highest $\mathrm{Hg}(0)$ concentrations at TR.

During the winter expedition ANTXXIX/6 on board R/V Polarstern over the Weddell Sea (Fig. 1), Nerentorp Mastromonaco et al. (2016) observed depletions of $\mathrm{Hg}(0)$ characterized by strong correlations with $\mathrm{O}_{3}$. This is the first evidence of $\mathrm{Hg}(0)$ depletions occurring in winter. The authors propose a dark mechanism involving $\mathrm{Br}_{2}$. AMDEs in Antarctica are operationally defined as $\mathrm{Hg}(0)$ concentrations below $0.60 \mathrm{ng} \mathrm{m}^{-3}$ (Pfaffhuber et al., 2012). Based on this threshold and on the $\mathrm{O}_{3}$ signal, there is no evidence of $\mathrm{Hg}(0)$ depletions occurring during months of complete darkness at the three ground-based Antarctic sites.

\section{Springtime AMDEs}

Before going further, it should be noted that TR is not a coastal station. It is located at an elevation of $1275 \mathrm{~m}$ and approximately $220 \mathrm{~km}$ from the Antarctic coast. Contrarily, DDU is located on a small island about $1 \mathrm{~km}$ offshore from the Antarctic mainland.

AMDEs are observed at TR in positive correlation with $\mathrm{O}_{3}$ ( $\mathrm{r}$ up to $0.56, p$ value $<0.001$, Spearman test). Based on the $0.60 \mathrm{ng} \mathrm{m}^{-3}$ threshold (see previous section), AMDEs occur in $2 \%$ of the springtime observations, in line with the occurrence frequency of $5 \%$ reported by Pfaffhuber et al. (2012) from February 2007 to June 2011. Based on a statistical analysis of source and sink regions, Pfaffhuber et al. (2012) indicated that the spring $\operatorname{Hg}(0)$ sink, caused by AMDEs, is mainly located within sea-ice-dense areas surrounding Queen Maud Land. AMDEs at TR are weaker and less frequent when compared to the Arctic (see Sect. 3.1.1) likely partly due to the location of the station not being exposed directly to depletion events but rather to transport of mercury-depleted air masses (Pfaffhuber et al., 2012). In contrast, AMDEs occur in $28 \%$ of the observations from $28 \mathrm{Au}-$ gust to 5 October 2013 during the spring expedition ANTXXIX/7 over sea-ice areas of the Weddell Sea. At DDU, on the other side of the Antarctic continent, data covering the spring period are scarce (Table 3). As indicated by Angot et al. (2016a), the absence of depletions in spring 2012 tends to suggest that AMDEs, if any, are not very frequent at DDU. Several studies reported a less efficient bromine chemistry in East compared to West Antarctica due to less 
sea-ice coverage (Theys et al., 2011; Legrand et al., 2016a). However, Angot et al. (2016a) reported low $\mathrm{Hg}(0)$ concentrations $\left(0.71 \pm 0.11 \mathrm{ng} \mathrm{m}^{-3}\right)$ and a significant positive correlation with $\mathrm{O}_{3}$ ( $r$ up to $0.65, p$ value $<0.0001$, Spearman test) in springtime oceanic air masses, likely due to bromine chemistry.

\section{Boundary layer dynamics on the Antarctic Plateau in fall}

The fall maximum at DC likely partly results from a low boundary layer oxidative capacity under low solar radiation limiting $\operatorname{Hg}(0)$ oxidation. Additionally, at DC, weak turbulence and mixing and strong temperature gradients near the surface are favored by light wind and clear sky conditions (Argentini et al., 2013). The surface-based temperature inversions were characterized by Pietroni et al. (2012) over the course of a year. In summer, a convective boundary layer characterized by a maximum depth of 200-400 m (Argentini et al., 2005) develops around midday. In winter, strong temperature inversions allow for a mixing depth of a few tens of meters only. Based on the limited area model MAR (Modèle Atmosphérique Régional), Angot et al. (2016b) indicated that the fall distinct maximum of $\operatorname{Hg}(0)$ concentrations is concomitant with the time when the boundary layer lowers to $\sim 50 \mathrm{~m}$ on average and no longer exhibits a pronounced diurnal cycle. $\operatorname{Hg}(0)$ is thus suddenly dispersed into a reduced volume of air, limiting the dilution. Similarly, several studies showed that $\mathrm{NO}_{x}$ mixing ratios are enhanced when the boundary layer is shallow (Neff et al., 2008; Frey et al., 2013).

\section{Extremely active processes in summertime}

Summertime $\operatorname{Hg}(0)$ concentrations at the three ground-based sites exhibit a high variability (Fig. 2b), suggesting extremely active processes at this time of the year. Undetected from March to October, a diurnal cycle characterized by a noon $\operatorname{Hg}(0)$ maximum is observed in summer at DDU and DC over the 2012-2015 period (Angot et al., 2016a, b). At DC (DDU), $\mathrm{Hg}(0)$ concentrations range from $\sim 0.6 \mathrm{ng} \mathrm{m}^{-3}\left(\sim 0.7 \mathrm{ng} \mathrm{m}^{-3}\right)$ on average at night to $\sim 1.0 \mathrm{ng} \mathrm{m}^{-3}\left(\sim 1.1 \mathrm{ng} \mathrm{m}^{-3}\right)$ on average around midday. Conversely, there is no diurnal variation in $\mathrm{Hg}(0)$ concentrations at TR, in good agreement with observations reported by Pfaffhuber et al. (2012) from February 2007 to June 2011. Similarly, there is no mention of a daily cycle at NM, Terra Nova Bay, and McMurdo where summer campaigns were carried out (Ebinghaus et al., 2002; Temme et al., 2003; Sprovieri et al., 2002; Brooks et al., 2008b). The absence of diurnal cycle at TR can be attributed to the absence of sources/sinks for $\mathrm{Hg}(0)$ with a diurnal cycle in the vicinity of the site (Pfaffhuber et al., 2012). The mean summertime $\mathrm{Hg}(0)$ concentration is significantly ( $p$ value $<0.0001$, Mann-Whitney test) lower at DC $\left(0.78 \pm 0.46 \mathrm{ng} \mathrm{m}^{-3}\right)$ than at DDU $\left(0.88 \pm 0.32 \mathrm{ng} \mathrm{m}^{-3}\right)$ and TR $\left(0.89 \pm 0.29 \mathrm{ng} \mathrm{m}^{-3}\right)$, suggesting a more intense oxidation of $\mathrm{Hg}(0)$. The boundary layer oxidative capacity has been shown to be high in summer on the Antarctic Plateau with elevated levels of $\mathrm{OH}$, $\mathrm{O}_{3}, \mathrm{NO}_{x}$, and $\mathrm{RO}_{2}$ radicals (Davis et al., 2001; Grannas et al., 2007; Eisele et al., 2008; Kukui et al., 2014; Frey et al., 2015). Angot et al. (2016b) performed $\mathrm{Hg}(0)$ measurements in both the atmospheric boundary layer and the interstitial air of the snowpack and analyzed total mercury in surface snow samples. The authors, in good agreement with Brooks et al. (2008a) and Dommergue et al. (2012), suggested that the observed summertime $\mathrm{Hg}(0)$ diurnal cycle at DC might be due to a dynamic daily cycle of $\mathrm{Hg}(0)$ oxidation, deposition to the snowpack, and re-emission from the snowpack. Similarly, a recent study (Wang et al., 2016) reported a $\mathrm{Hg}(0)$ diurnal cycle at Kunlun station $\left(80^{\circ} 25^{\prime} \mathrm{S}\right.$, $\left.77^{\circ} 6^{\prime} \mathrm{E}\right)$ located near Dome A $\left(80^{\circ} 22^{\prime} \mathrm{S}, 77^{\circ} 27^{\prime} \mathrm{E}\right)$ - the highest elevation point on the Antarctic Plateau $(4090 \mathrm{~m})$. This suggests that the dynamic daily cycle of $\mathrm{Hg}(0)$ oxidation, deposition to the snowpack, and re-emission from the snowpack probably occurs throughout the Antarctic Plateau. Based on an analysis of air mass back trajectories, Angot et al. (2016a) showed that measurements at DDU on the East Antarctic coast are dramatically influenced by air masses exported from the Antarctic Plateau by strong katabatic winds. The advection of inland air masses enriched in oxidants $\mathrm{NO}_{x}, \mathrm{O}_{3}$, and $\mathrm{OH}$ (Grilli et al., 2013; Kukui et al., 2012) - and $\mathrm{Hg}$ (II) species likely results in the buildup of an atmospheric reservoir of $\mathrm{Hg}$ (II) species at DDU, as supported by elevated levels of total mercury in surface snow samples (Angot et al., 2016a). The diurnal cycle observed at DDU regardless of wind speed and direction - might result from a local dynamic cycle of oxidation/deposition/re-emission in the presence of elevated levels of $\mathrm{Hg}$ (II) species along with emissions of mercury from ornithogenic soils - formed by an accumulation of penguin excreta.

$\mathrm{Hg}(0)$ depletion events occur each year in summer at DC with $\mathrm{Hg}(0)$ concentrations remaining low $\left(\sim 0.40 \mathrm{ng} \mathrm{m}^{-3}\right)$ for several weeks. These depletion events do not resemble to the ones observed in the Arctic. They are not associated with depletions of $\mathrm{O}_{3}$ and occur as air masses stagnate over the Plateau, which could favor an accumulation of oxidants within the shallow boundary layer (Angot et al., 2016b). At TR, Pfaffhuber et al. (2012) reported episodic low $\mathrm{Hg}(0)$ concentrations in summer, anticorrelated with $\mathrm{O}_{3}$, and associated with the transport of inland air masses. Results at TR (Pfaffhuber et al., 2012) and DDU (Angot et al., 2016a), along with observations from earlier studies at other coastal Antarctic sites (Sprovieri et al., 2002; Temme et al., 2003), demonstrate that the inland atmospheric reservoir can influence the cycle of atmospheric mercury at a continental scale, especially in areas influenced by recurrent katabatic winds.

Additionally, Pfaffhuber et al. (2012) indicated that the ocean is a source of mercury to TR. Similarly, at DDU, Angot et al. (2016a) reported elevated $\left(1.04 \pm 0.29 \mathrm{ng} \mathrm{m}^{-3}\right) \mathrm{Hg}(0)$ 
concentrations in oceanic air masses along with a significant positive correlation between $\operatorname{Hg}(0)$ and the daily-averaged percentage of oceanic air masses $(r=0.50, p$ value $<0.0001$, Spearman test). These results are in line with the summer $\mathrm{Hg}(0)$ enhancement in the Arctic likely partly due to oceanic evasion from ice-free open waters (see Sect. 3.1.1).

\subsubsection{Comparison with models}

Table 4 displays goodness-of-fit statistics between monthlyaveraged modeled and observed data in 2013. ECHMERIT slightly underestimates $\operatorname{Hg}(0)$ concentrations at the three ground-based Antarctic sites. Contrarily, the three other global models overestimate $\mathrm{Hg}(0)$ levels, suggesting an underestimation of sinks. The ability of the four models to reproduce the observed seasonality of $\mathrm{Hg}(0)$ concentrations at ground-based Antarctic sites in 2013 is shown in Fig. 6b and discussed in the following sections. The interannual variability of the monthly $\mathrm{Hg}(0)$ concentration distribution at Antarctic ground-based sites as simulated by GEM-MACH-Hg and GEOS-Chem is displayed in Fig. 7b while Table 5 shows the percent bias between hourly-averaged modeled and observed data on a seasonal basis from 2011 to 2014.

\section{Seasonal variation}

\section{(a) Winter}

GEOS-Chem, GEM-MACH-Hg, and GLEMOS overestimate year $2013 \mathrm{Hg}(0)$ concentrations in winter at the three ground-based stations (Fig. 6a). This trend repeats year after year for GEOS-Chem and GEM-MACH-Hg (Table 5). The most striking result, however, is the modeled gradual increase of $\mathrm{Hg}(0)$ concentrations over the course of winter at the three ground-based sites according to ECHMERIT, GEOS-Chem, and GEM-MACH-Hg. A mean gradual increase of 9,19 , and $11 \%$ is predicted by the three models, respectively, from May to August. GLEMOS, however, predicts a mean gradual decrease of $5 \%$ over the course of winter at the three sites. It is to be noted (see Sect. 3.2.1) that $\mathrm{Hg}(0)$ concentrations are constant from May to August at TR and exhibit a gradual $30 \%$ decrease at DC possibly due to the dry deposition of $\mathrm{Hg}(0)$ and a gradual $20 \%$ decrease at DDU due to advection of inland air masses. All in all, the four models misrepresent the decreasing trend at DC and DDU. This might be due to several factors including underestimation of concentrations of oxidants over the East Antarctic Plateau at this period of the year, omission of heterogeneous mechanisms, and significant bias in southern hemispheric emissions, including oceanic evasion. The strong increase (19\%) of $\mathrm{Hg}(0)$ concentrations from May to August predicted by GEOS-Chem is not restricted to the Antarctic continent but is obtained for the whole Southern Hemisphere (Fig. 3 in Song et al., 2015). The emission inversion performed by Song et al. (2015) overturns the seasonality of oceanic emissions and better reproduces the ground-based $\mathrm{Hg}(0)$ observations in the southern hemispheric midlatitudes and at TR. Further work, including sensitivity tests, is needed to explain the discrepancies between observed and modeled trends.

Additionally, all of the four models are unable to capture the differences in trends observed at the three groundbased sites (constant vs. decreasing concentrations). As discussed in Sect. 3.2.1, TR, contrarily to DDU, is not significantly influenced by inland air masses. This large-scale airflow pattern will have to be captured by models in order to better reproduce observations. Interestingly, Zatko et al. (2016) calculated the annual mean surface wind convergence/divergence over the Antarctic continent using GEOSChem. The results - consistent with those by Parish and Bromwich (1987) and Parish and Bromwich (2007) - correctly indicate that the large-scale airflow pattern in Antarctica flows from the East Antarctic Plateau towards the coastal margins and accurately highlight major regions of wind convergence. The findings from this study can be used as the basis for future research.

\section{(b) Spring}

Based on the $0.60 \mathrm{ng} \mathrm{m}^{-3}$ threshold, GEM-MACH-Hg and GEOS-Chem do not predict any AMDE at TR over the 20112014 period. Considering the low occurrence frequency based on observations ( $2 \%$, see Sect. 3.2.1), this result is not unreasonable. Similarly, GEM-MACH-Hg does not predict any AMDE at DDU. However, GEOS-Chem predicts AMDEs in $1.5 \%$ of the springtime observations at DDU. This overprediction of AMDEs at DDU likely results from the constant value of 5 pptv of $\mathrm{BrO}$ added in the springtime Antarctic boundary layer. While Saiz-Lopez et al. (2007) reported a spring maximum of up to $7 \mathrm{pptv}$ at Halley Station $\left(75^{\circ} 35^{\prime} \mathrm{S}, 26^{\circ} 30^{\prime} \mathrm{W}\right.$, West Antarctic coast), Legrand et al. (2016a) suggested a BrO mixing ratio $\leq 1 \mathrm{pptv}$ at DDU (East Antarctic coast) in spring using an offline chemistry transport model. Based on the oxygen and nitrogen isotope analysis of airborne nitrate, Savarino et al. (2007) provided further evidence for low BrO levels in the vicinity of DDU.

\section{(c) Fall}

None of the four models capture the fall maximum at DC (Fig. 6b). While a spatially and temporally resolved distribution of concentrations of oxidants on the East Antarctic Plateau is needed, the boundary layer dynamics must also be taken into account. Based on the work by Lin and McElroy (2010), Zatko et al. (2016) incorporated a calculation of the boundary layer height across Antarctica and Greenland into GEOS-Chem. One could also rely on model outputs from the limited area model MAR, validated against observations at DC (Gallée and Gorodetskaya, 2010; Gallée et al., 2015). This model agrees very well with observations and provides reliable and useful information about surface turbu- 
lent fluxes, vertical profiles of vertical diffusion coefficients, and boundary layer height.

\section{(d) Summer}

The daily variation of $\mathrm{Hg}(0)$ concentrations was investigated based on hourly-averaged data provided by GEOS-Chem and GEM-MACH-Hg. The two models are not able to reproduce the noon maximum observed at DC and DDU in summer (Sect. 3.2.1), suggesting that the dynamic daily cycle of deposition and re-emission at the air/snow interface is not captured by the models. The bidirectional exchange of $\operatorname{Hg}(0)$ is complex and influenced by multiple environmental variables (e.g., UV intensity, temperature, atmospheric turbulence, presence of reactants) limiting the accuracy of flux modeling (Zhu et al., 2016). The work carried out by Durnford et al. (2012) in the Arctic and by Zatko et al. (2016) in Antarctica could be good starting points for future research. The former developed a new dynamic physically based snowpack model to determine the fate of mercury deposited onto snowpacks; the latter incorporated an idealized snowpack along with a snow radiative transfer model (Zatko et al., 2013) into GEOS-Chem to investigate the impact of snow nitrate photolysis on the boundary layer chemistry across Antarctica.

\section{Reactive mercury and deposition}

According to Fig. 8b, ECHMERIT predicts low RM concentrations during the whole 2013 year at the three groundbased stations (annual averages of 10, 7, and $6 \mathrm{pg} \mathrm{m}^{-3}$ at TR, DC, and DDU, respectively). GEOS-Chem predicts a peak in spring at the three sites (up to $\sim 160 \mathrm{pg} \mathrm{m}^{-3}$ on average October at DC) and quite elevated concentrations in summer and fall ( $\sim 85 \mathrm{pg} \mathrm{m}^{-3}$ on average). GEM-MACH-Hg predicts increased concentrations in summer at TR and DDU only. Finally, GLEMOS predicts a more intense summer peak at DC (up to $\sim 130 \mathrm{pg} \mathrm{m}^{-3}$ on average in November) than at DDU and TR. Measurements of RM are scarce in Antarctica and have never been reported on a year-round basis. $\mathrm{RM}$ concentrations ranging from 100 to $1000 \mathrm{pg} \mathrm{m}^{-3}$ have been reported in summer at South Pole (Brooks et al., 2008a) and several studies have reported elevated concentrations at coastal sites in spring during the AMDEs season $\left(165 \mathrm{pg} \mathrm{m}^{-3}\right.$ on average at McMurdo; Brooks et al., 2008b) and in summer (mean RGM concentration of $116 \mathrm{pg} \mathrm{m}^{-3}$ at Terra Nova Bay (Sprovieri et al., 2002); RGM and $\mathrm{Hg}(\mathrm{p})$ concentrations ranging from 5 to $>300 \mathrm{pg} \mathrm{m}^{-3}$ and from 15 to $120 \mathrm{pg} \mathrm{m}^{-3}$, respectively, at Neumayer (Temme et al., 2003)). These results along with the seasonal pattern of $\operatorname{Hg}(0)$ reported in Sect. 3.2.1 suggest that the atmospheric boundary layer is enriched in RM in summer, especially on the Antarctic Plateau, and that the four models tend to underestimate the summertime concentrations. Year-round measurements are needed to further evaluate the accuracy of models predictions.
The total (wet + dry) deposition flux for year 2013 is equal to $1.0,3.3,2.5$, and $3.9 \mu \mathrm{g} \mathrm{m}^{-2} \mathrm{yr}^{-1}$ at TR, 0.8, 1.5, 0.8, and $1.1 \mu \mathrm{g} \mathrm{m}^{-2} \mathrm{yr}^{-1}$ at DC, and 4.3, 9.7, 9.7, and $4.1 \mu \mathrm{g} \mathrm{m}^{-2} \mathrm{yr}^{-1}$ at DDU according to GLEMOS, GEOSChem, GEM-MACH-Hg, and ECHMERIT, respectively. Deposition during summertime accounts for $73,53,68$, and $35 \%$ of the total deposition at TR, 58, 50, 37, and $35 \%$ at DC, and 58, 61, 89, and $28 \%$ at DDU according to GLEMOS, GEOS-Chem, GEM-MACH-Hg, and ECHMERIT, respectively. There are no measurements of wet and dry deposition in Antarctica except from Angot et al. (2016b), who reported a $\mathrm{Hg}(0)$ dry deposition velocity of $9.3 \times 10^{-5} \mathrm{~cm} \mathrm{~s}^{-1}$ in winter at DC. Similarly to the Arctic (see Sect. 3.1.2), deposition of mercury is typically inferred from concentrations of total mercury in the snowpack. To the best of our knowledge, results found in Angot et al. (2016b) are the only reported over various seasons. Higher total mercury concentrations in surface snow samples in summer suggest an enhanced deposition at this period of the year. Alternatively, deposition of mercury can be inferred from the biomonitoring of Antarctic macrolichens and mosses (Bargagli, 2016). Large-scale and long-term biomonitoring surveys of mercury deposition have been performed in Victoria Land (Bargagli et al., 1993, 2005). While all four models predict higher total mercury deposition for year 2013 at high Arctic (ALT, SND, NYA) vs. Antarctic ground-based sites, significantly higher mercury concentrations in Antarctic vs. northern hemispheric lichens suggest otherwise (Bargagli et al., 1993).

Wet deposition accounts for $14,53,47$, and $0 \%$ of the total (wet + dry) flux at TR, 35, 7, 14, and $0 \%$ at DC, and $68,57,60$, and $8 \%$ at DDU according to GLEMOS, GEOS-Chem, GEM-MACH-Hg, and ECHMERIT, respectively. The amount of precipitation is equal to 214,242 , 291 , and $1127 \mathrm{~mm} \mathrm{yr}^{-1}$ at TR, 33, 29, 24, and $60 \mathrm{~mm} \mathrm{yr}^{-1}$ at DC and 643, 792, 895, and $1751 \mathrm{~mm} \mathrm{yr}^{-1}$ at DDU according to GLEMOS, GEOS-Chem, GEM-MACH-Hg, and ECHMERIT, respectively. Ground-based measurements of precipitation are sparse and difficult to obtain in Antarctica. Strong winds in coastal regions make it difficult to tell the difference between blowing snow and precipitation (Palerme et al., 2014). On the Antarctic Plateau, a significant part of the precipitation falls in the form of ice crystals (diamond dust) under clear-sky conditions (Bromwich, 1988; Fujita and Abe, 2006). Satellite observations of precipitation in Antarctica by active sensors are now possible (Liu, 2008; Stephens et al., 2008). According to Palerme et al. (2014), the mean annual snowfall rate is $<20 \mathrm{~mm}$ water equivalent $\mathrm{yr}^{-1}$ at DC and ranges from 20 to $100 \mathrm{~mm} \mathrm{yr}^{-1}$ at TR and from 500 to $700 \mathrm{~mm} \mathrm{yr}^{-1}$ at DDU. The low amount of precipitation at DC might, however, be offset by the high mercurycapture efficiency of ice crystals (Douglas et al., 2008) that are frequently observed at that site (Bromwich, 1988; Fujita and Abe, 2006). 


\section{Summary and future perspectives}

The data compiled in this study represent the latest available in polar regions. While the Arctic is a semi-enclosed ocean almost completely surrounded by land, Antarctica is a land mass - covered with an immense ice shelf - surrounded by ocean. Therefore, the cycle of atmospheric mercury in the two regions presents both similarities and differences. Springtime AMDEs are observed in both regions at coastal sites (see Sect. 3.1.1 and Sect. 3.2.1). Their frequency and magnitude depend on parameters such as sea-ice dynamics, temperature, and concentration of bromine species and exhibit a significant but poorly understood interannual variability. Additionally, coastal sites in the two regions are influenced by both snowpack re-emission and oceanic evasion of $\mathrm{Hg}(0)$ in summer. As evidenced in Sect. 3.1.1, the summertime enhancement of $\mathrm{Hg}(0)$ concentrations exhibits a significant but little understood interannual variability at Arctic sites. The cycle of atmospheric mercury differs between the Arctic and Antarctica, primarily because of their different geography. Arctic sites are significantly influenced by mercury emissions from northern hemispheric midlatitudes - especially in winter (see Sect. 3.1.1). Coastal Antarctic sites are significantly influenced by the reactivity of atmospheric mercury observed on the Antarctic Plateau due to the large-scale airflow pattern flowing from the East Antarctic ice sheet towards the coastal margins (katabatic winds). As discussed in Sect. 3.2, the cycle of atmospheric mercury on the Antarctic Plateau is surprising and involves yet unraveled mechanisms in winter and a daily bidirectional exchange of $\operatorname{Hg}(0)$ at the air/snow interface in summer.

From the comparison of multi-model simulations with observations, we identified whether the processes that affect $\mathrm{Hg}(0)$ seasonality and interannual variability, including mercury oxidation, deposition, and re-emission, are appropriately understood and represented in the models. Generally, models reproduce quite fairly the observed seasonality at Arctic sites but fail to reproduce it at Antarctic sites. In order for the models to reproduce the seasonality of $\mathrm{Hg}(0)$ concentrations in Antarctica, parameterization of the boundary layer dynamics and of the large-scale airflow pattern is needed. Moreover, reaction pathways might be missing or inappropriately incorporated in models. Heterogeneous reactions, although poorly understood (Subir et al., 2012), might be required to explain the reactivity on the Antarctic Plateau. Additionally, while $\mathrm{NO}_{x}$ chemistry was shown to prevail upon halogens chemistry in East Antarctica in summer (Legrand et al., 2009; Grilli et al., 2013) it is currently incorporated in none of the four global models.

Based on this study, the following research gaps need to be addressed:

1. Improving the spatial resolution of RM measurements. There are presently no year-round data available in Antarctica. The Tekran speciation unit suffers from sig- nificant biases and interferences, is expensive and laborintensive, and requires trained operators. Passive samplers, such as polyethersulfone cation exchange membranes, could provide an alternative (Huang et al., 2014) but further tests are needed to assess their collection efficiency and potential biases.

2. Unraveling of $\mathrm{Hg}(\mathrm{II})$ speciation. The exact speciation - expected to vary with space and time - remains unknown. Identification of $\mathrm{Hg}$ (II) species in ambient air emerges as one of the priorities for future research (Gustin et al., 2015). Recent advancement on analytical techniques may offer new insights into $\mathrm{Hg}$ (II) speciation (Huang et al., 2013; Jones et al., 2016) but further research is still needed. Such advancement will greatly improve our understanding of atmospheric redox processes.

3. Improving the spatial resolution of measurements of total mercury in snow samples. These measurements are an alternative to wet and dry deposition measurements - difficult to perform in polar regions.

4. Investigation of the fundamental environmental processes driving the interannual variability of $\mathrm{Hg}(0)$ concentrations, especially at Arctic sites. Further work is needed to establish the degree to which temperature and sea-ice dynamics across the Arctic alters mercury chemistry in spring and summer. This will also open up new opportunities to explore the influence of climate change on the cycle of mercury in polar regions.

5. Investigation (and quantification) of the oceanic fluxes of $\mathrm{Hg}(0)$ during oceanographic campaigns across the Arctic and Austral oceans. This will largely reduce the uncertainty in the mercury budget estimation in polar regions.

6. Reducing uncertainties in existing kinetic parameters and quantitatively investigate the effect of temperature on the rate constants (Subir et al., 2011). Limited data are available for temperature applicable to atmospheric conditions, especially in polar regions. Achieving this will largely reduce uncertainties in atmospheric models.

7. Investigation of the influence of atmospheric surfaces (e.g., aerosols, clouds, ice, snow covers, ice crystals). This is a major gap for adequate modeling of mercury cycling (Subir et al., 2012) and studies addressing this are critically needed.

\section{Data availability}

Mercury data reported in this paper are available upon request at http://sdi.iia.cnr.it/geoint/publicpage/GMOS/gmos_ historical.zul (GMOS, 2016). 
Acknowledgements. Hélène Angot, Olivier Magand, and Aurélien Dommergue thank the overwintering crew: S. Aguado, D. Buiron, N. Coillard, G. Dufresnes, J. Guilhermet, B. Jourdain, B. Laulier, S. Oros, A. Thollot, and N. Vogel at DDU, S. Aubin, A. Barbero, N. Hueber, C. Lenormant, and R. Jacob at DC. This work contributed to the EU-FP7 project Global Mercury Observation System (GMOS, www.gmos.eu) and has been supported by a grant from Labex OSUG@2020 (Investissements d'avenir - ANR10 LABX56) and the Institut Universitaire de France. Logistical and financial support was provided by the French Polar Institute IPEV (Program 1028, GMOstral). Katrine A. Pfaffhuber thanks the Norwegian Environmental Agency and the Norwegian Antarctic Research Expeditions for long-term financial support of Norwegian mercury measurements and in particular the technicians J. H. Wasseng and A. Bäcklund at NILU for their excellent care taking of the Tekran monitors. Noelle E. Selin and Shaojie Song acknowledge support from the US National Science Foundation Atmospheric Chemistry Program under grant no. 1053648. Aurélien Dommergue, Hélène Angot, Noelle E. Selin, and Shaojie Song acknowledge the MIT-France Seed Fund.

Edited by: N. Pirrone

Reviewed by: L.-E. Heimburger and one anonymous referee

\section{References}

ECMWF: European Centre for Medium-Range Weather Forecasts, available at: http://www.ecmwf.int/en/forecasts/datasets, last access: 20 January 2016.

Adams, J. W., Holmes, N. S., and Crowley, J. N.: Uptake and reaction of $\mathrm{HOBr}$ on frozen and dry $\mathrm{NaCl} / \mathrm{NaBr}$ surfaces between 253 and 233 K, Atmos. Chem. Phys., 2, 79-91, doi:10.5194/acp2-79-2002, 2002.

AMAP: Human Health in the Arctic, Arctic Monitoring and Assessment Programme (AMAP), Oslo, Norway, 165 pp., 2015.

Amos, H. M., Jacob, D. J., Holmes, C. D., Fisher, J. A., Wang, Q., Yantosca, R. M., Corbitt, E. S., Galarneau, E., Rutter, A. P., Gustin, M. S., Steffen, A., Schauer, J. J., Graydon, J. A., Louis, V. L. St., Talbot, R. W., Edgerton, E. S., Zhang, Y., and Sunderland, E. M.: Gas-particle partitioning of atmospheric $\mathrm{Hg}(\mathrm{II})$ and its effect on global mercury deposition, Atmos. Chem. Phys., 12, 591-603, doi:10.5194/acp-12-591-2012, 2012.

Amos, H. M., Sonke, J. E., Obrist, D., Robins, N., Hagan, N., Horowitz, H. M., Mason, R. P., Witt, M. L. I., Hedgecock, I. M., Corbitt, E. S., and Sunderland, E. M.: Observational and modeling constraints on global anthropogenic enrichment of mercury, Environ. Sci. Technol., 49, 4036-4047, 2015.

Andersson, M. E. S. J., Gårdfeldt, K., and Linfqvist, O.: Enhanced concentrations of dissolved gaseous mercury in the surface waters of the Arctic Ocean, Marine Chem., 110, 190-194, 2008.

Angot, H., Barret, M., Magand, O., Ramonet, M., and Dommergue, A.: A 2-year record of atmospheric mercury species at a background Southern Hemisphere station on Amsterdam Island, Atmos. Chem. Phys., 14, 11461-11473, doi:10.5194/acp14-11461-2014, 2014.

Angot, H., Dion, I., Vogel, N., Legrand, M., Magand, O., and Dommergue, A.: Multi-year record of atmospheric mercury at Dumont d'Urville, East Antarctic coast: continental outflow and oceanic influences, Atmos. Chem. Phys., 16, 8265-8279, doi:10.5194/acp-16-8265-2016, 2016a.

Angot, H., Magand, O., Helmig, D., Ricaud, P., Quennehen, B., Gallée, H., Del Guasta, M., Sprovieri, F., Pirrone, N., Savarino, J., and Dommergue, A.: New insights into the atmospheric mercury cycling in central Antarctica and implications on a continental scale, Atmos. Chem. Phys., 16, 8249-8264, doi:10.5194/acp-168249-2016, 2016b.

Argentini, S., Viola, A., Sempreviva, A. M., and Petenko, I.: Summer boundary-layer height at the plateau site of Dome C, Antarctica, Bound.-Lay. Meteorol., 115, 409-422, 2005.

Argentini, S., Petenko, I., Viola, A., Mastrantonio, G., Pietroni, I., Casasanta, G., Aristidi, E., and Ghenton, C.: The surface layer observed by a high-resolution sodar at Dome C, Antarctica, Annals of Geophysics, 56, doi:10.4401/ag-6347, 2013.

Ariya, P. A., Dastoor, A. P., Amyot, M., Schroeder, W. H., Barrie, L., Anlauf, K., Raofie, F., Ryzhkov, A., Davignon, D., Lalonde, J., and Steffen, A.: The arctic: a sink for mercury, Tellus, 56B, 397-403, 2004.

Aspmo, K., Gauchard, P.-A., Steffen, A., Temme, C., Berg, T., Bahlmann, E., Banic, C., Dommergue, A., Ebinghaus, R., Ferrari, C., Pirrone, N., Sprovieri, F., and Wibetoe, G.: Measurements of atmospheric mercury species during an international study of mercury depletion events at Ny-Ålesund, Svalbard, spring 2003. How reproductible are our present methods?, Atmos. Environ., 39, 7607-7619, 2005.

Aspmo, K., Temme, C., Berg, T., Ferrari, C., Gauchard, P.-A., Faïn, X., and Wibetoe, G.: Mercury in the atmosphere, snow and melt water ponds in the north atlantic ocean during Arctic summer, Environ. Sci. Technol., 40, 4083-4089, 2006.

Balabanov, N. B., Shepler, B. C., and Peterson, K. A.: Accurate Global Potential Energy Surface and Reaction Dynamics for the Ground State of HgBr2, J. Phys. Chem. A, 109, 8765-8773, doi:10.1021/jp0534151, 2005.

Bargagli, R.: Moss and lichen biomonitoring of atmospheric mercury: a review, Sci. Total Environ., 572, 216-231, 2016.

Bargagli, R., Battisti, E., Focardi, S., and Formichi, P.: Preliminary data on environmental distribution of mercury in northern Victoria Land, Antarctica, Antarctic Sci., 5, 3-8, 1993.

Bargagli, R., Agnorelli, C., Borghini, F., and Monaci, F.: Enhanced deposition and bioaccumulation of mercury in antarctic terrestrial ecosystems facing a coastal polynya, Environ. Sci. Technol., 39, 8150-8155, 2005.

Barrie, L. A., Hoff, R. M., and Daggupaty, S. M.: Arctic Air Chemistry Proceedings of the Second SymposiumThe influence of mid-latitudinal pollution sources on haze in the Canadian arctic, Atmos. Environ. (1967), 15, 1407-1419, doi:10.1016/00046981(81)90347-4, 1981.

Berg, T., Bartnicki, J., Munthe, J., Lattila, H., Hrehoruk, J., and Mazur, A.: Atmospheric mercury species in the European Arctic: measurements and modelling, Atmos. Environ., 35, 2569-2582, 2001.

Berg, T., Sekkesæter, S., Steinnes, E., Valdal, A.-K., and Wibetoe, G.: Springtime depletion of mercury in the European Arctic as observed at Svalbard, Sci. Total Environ., 304, 43-51, doi:10.1016/S0048-9697(02)00555-7, 2003a.

Berg, T., Sommar, J., Wängberg, Gardfeldt, K., Munthe, J., and Schroeder, B.: Arctic mercury depletion events at two elevations 
as observed at the Zeppelin Station and Dirigibile Italia, NyÅlesund, spring 2002, J. Phys. IV France, 107, 151-154, 2003 b.

Berg, T., Aspmo, K., and Steinnes, E.: Transport of $\mathrm{Hg}$ from atmospheric mercury depletion events to the mainland of Norway and its possible influence on $\mathrm{Hg}$ deposition, Geophysical Res. Lett., 35, L09802, doi:10.1029/2008GL033586, 2008.

Berg, T., Pfaffhuber, K. A., Cole, A. S., Engelsen, O., and Steffen, A.: Ten-year trends in atmospheric mercury concentrations, meteorological effects and climate variables at Zeppelin, NyÅlesund, Atmos. Chem. Phys., 13, 6575-6586, doi:10.5194/acp13-6575-2013, 2013.

Bey, I., Jacob, D. J., Yantosca, R. M., Logan, J. A., Field, B. D., Fiore, A. M., li, Q., Liu, H. Y., Mickley, L. J., and Schultz, M. G.: Global modeling of tropospheric chemistry with assimilated meteorology: model description and evaluation, J. Geophys. Res., 106, 23073-23095, 2001.

Bilello, M. A.: Prevailing wind directions in the Arctic Ocean, Corps of Engineers, U.S. Army: Hanover, New Hampshire, 38, 1973.

Bloom, N. S. and Fitzgerald, W. F.: Determination of volatile mercury species at the picogram level by low temperature gas chromatography with cold-vapor atomic fluorescence detection, Anal. Chim. Acta, 208, 151-161, 1988.

Bourgeois, Q. and Bey, I.: Pollution transport efficiency toward the Arctic: senstivity to aerosol scavenging and source regions, J. Geophys. Res., 116, D08213, doi:10.1029/2010JD015096, 2011.

Bromwich, D. H.: Snowfall in high southern latitudes, Rev. Geophys., 26, 149-168, doi:10.1029/RG026i001p00149, 1988.

Brooks, S., Saiz-Lopez, A., Skov, H., Lindberg, S. E., Plane, J. M. C., and Goodsite, M. E.: The mass balance of mercury in the springtime arctic environment, Geophys. Res. Lett., 33, L13812, doi:10.1029/2005GL025525, 2006.

Brooks, S. B., Arimoto, R., Lindberg, S. E., and Southworth, G.: Antarctic polar plateau snow surface conversion of deposited oxidized mercury to gaseous elemental mercury with fractional long-term burial, Atmos. Environ., 42, 2877-2884, 2008a.

Brooks, S. B., Lindberg, S. E., Southworth, G., and Arimoto, R.: Springtime atmospheric mercury speciation in the McMurdo, Antarctica coastal region, Atmos. Environ., 42, 2885-2893, 2008 b.

Cadle, S. H.: Dry Deposition to Snowpacks, in: Seasonal Snowpacks: Processes of Compositional Change, edited by: Davies, T. D., Tranter, M., and Jones, H. G., Springer Berlin Heidelberg, Berlin, Heidelberg, 21-66, 1991.

Chen, L., Zhang, Y., Jacob, D. J., Soerensen, A. L., Fisher, J. A., Horowitz, H. M., Corbitt, E. S., and Wang, X.: A decline in Arctic Ocean mercury suggested by differences in decadal trends of atmospheric mercury between the Arctic and northern midlatitudes, Geophys. Res. Lett., 42, 6076-6083, doi:10.1002/2015GL064051, 2015.

Cobbett, F. D., Steffen, A., Lawson, G., and Van Heyst, B. J.: GEM fluxes and atmospheric mercury concentrations (GEM, RGM and $\mathrm{Hg}(\mathrm{p}))$ in the Canadian Arctic at Alert, Nunavut, Canada (February-June 2005), Atmos. Environ., 41, 6527-6543, doi:10.1016/j.atmosenv.2007.04.033, 2007.

Cole, A. S. and Steffen, A.: Trends in long-term gaseous mercury observations in the Arctic and effects of temperature and other atmospheric conditions, Atmos. Chem. Phys., 10, 4661-4672, doi:10.5194/acp-10-4661-2010, 2010.
Cole, A. S., Steffen, A., Pfaffhuber, K. A., Berg, T., Pilote, M., Poissant, L., Tordon, R., and Hung, H.: Ten-year trends of atmospheric mercury in the high Arctic compared to Canadian subArctic and mid-latitude sites, Atmos. Chem. Phys., 13, 15351545, doi:10.5194/acp-13-1535-2013, 2013.

D’Amore, F., Bencardino, M., Cinnirella, S., Sprovieri, F., and Pirrone, N.: Data quality through a web-based QA/QC system: implementation for atmospheric mercury data from the Global Mercury Observation System, Environmental Science: Processes \& Impacts, 17, 1482-1491, 2015.

Dastoor, A. P. and Durnford, D. A.: Arctic ocean: is it a sink or a source of atmospheric mercury?, Environ. Sci. Technol., 48, 1707-1717, 2014.

Dastoor, A. P. and Larocque, Y.: Global circulation of atmospheric mercury: a modelling study, Atmos. Environ., 38, 147-161, 2004.

Dastoor, A. P., Davignon, D., Theys, N., Van Roozendael, M., Steffen, A., and Ariya, P. A.: Modeling dynamic exchange of gaseous elemental mercury at polar sunrise, Environ. Sci. Technol., 42, 5183-5188, 2008

Dastoor, A., Ryzhkov, A., Durnford, D., Lehnherr, I., Steffen, A., and Morrison, H.: Atmospheric mercury in the Canadian Arctic. Part II: Insight from modeling, Sci. Total Environ., 509-510, 1627, doi:10.1016/j.scitotenv.2014.10.112, 2015.

Davis, D., Nowak, J. B., Chen, G., Buhr, M., Arimoto, R., Hogan, A., Eisele, F., Mauldin, L., Tanner, D., Shetter, R., Lefer, B., and McMurry, P.: Unexpected high levels of NO observed at South Pole, Geophys. Res. Lett., 28, 3625-3628, 2001.

De Simone, F., Gencarelli, C. N., Hedgecock, I. M., and Pirrone, N.: Global atmospheric cycle of mercury: a model study on the impact of oxidation mechanisms, Environ. Sci. Pollut. Res., 21, 4110-4123, 2014.

De Simone, F., Gencarelli, C. N., Hedgecock, I. M., and Pirrone, N.: A Modeling Comparison of Mercury Deposition from current Anthropogenic Mercury Emission Inventories, Environ. Sci Technol., 50, 5154-5162, doi:10.1021/acs.est.6b00691, 2016.

Dibble, T. S., Zelie, M. J., and Mao, H.: Thermodynamics of reactions of $\mathrm{ClHg}$ and $\mathrm{BrHg}$ radicals with atmospherically abundant free radicals, Atmos. Chem. Phys., 12, 10271-10279, doi:10.5194/acp-12-10271-2012, 2012.

Dommergue, A., Larose, C., Faïn, X., Clarisse, O., Foucher, D., Hintelmann, H., Schneider, D., and Ferrari, C. P.: Deposition of Mercury Species in the Ny-Ålesund Area $\left(79^{\circ} \mathrm{N}\right)$ and Their Transfer during Snowmelt, Environ. Sci. Technol., 44, 901-907, doi:10.1021/es902579m, 2010a.

Dommergue, A., Sprovieri, F., Pirrone, N., Ebinghaus, R., Brooks, S., Courteaud, J., and Ferrari, C. P.: Overview of mercury measurements in the Antarctic troposphere, Atmos. Chem. Phys., 10, 3309-3319, doi:10.5194/acp-10-3309-2010, 2010 b.

Dommergue, A., Barret, M., Courteaud, J., Cristofanelli, P., Ferrari, C. P., and Gallée, H.: Dynamic recycling of gaseous elemental mercury in the boundary layer of the Antarctic Plateau, Atmos. Chem. Phys., 12, 11027-11036, doi:10.5194/acp-1211027-2012, 2012.

Donohoue, D. L., Bauer, D., Cossairt, B., and Hynes, A. J.: Temperature and pressure dependent rate coefficients for the reaction of $\mathrm{Hg}$ with $\mathrm{Br}$ and the reaction of $\mathrm{Br}$ with $\mathrm{Br}$ : a pulsed laser photolysis-pulsed laser induced fluorescence study, J. Phys. Chem., 110, 6623-6632, 2006. 
Douglas, T. A., Sturm, M., Simpson, W. R., Blum, J. D., AlvarezAviles, L., Keeler, G. J., Perovich, D. K., Biswas, A., and Johnson, K.: Influence of snow and ice crystal formation and accumulation on mercury deposition to the Arctic, Environ. Sci. Technol., 42, 1542-1551, 2008.

Douglas, T. A., Loseto, L. L., Macdonald, R. W., Outridge, P. M., Dommergue, A., Poulain, A. J., Amyot, M., Barkay, T., Berg, T., Chételat, J., Constant, P., Evans, M. J., Ferrari, C., Gantner, N., Johnson, M. S., Kirk, J., Kroer, N., Larose, C., Lean, D., Gissel Nielsen, T., Poissant, L., Rognerud, S., Skov, H., Sørensen, S., Wang, F., Wilson, S., and Zdanowicz, C.: The fate of mercury in Arctic terrestrial and aquatic ecosystems, a review, Environ. Chem., 9, 321-355, doi:10.1071/EN11140, 2012.

Driscoll, C. T., Mason, R. P., Chan, H. M., Jacob, D. J., and Pirrone, N.: Mercury as a global pollutant: sources, pathways, and effects, Environ. Sci. Technol., 47, 4967-4983, 2013.

Dumarey, R., Temmerman, E., Dams, R., and Hoste, J.: The accuracy of the vapour injection calibration method for the determination of mercury by amalgamation/cold vapour atomic spectrometry, Anal. Chim. Acta, 170, 337-340, 1985.

Durnford, D., Dastoor, A., Figueras-Nieto, D., and Ryjkov, A.: Long range transport of mercury to the Arctic and across Canada, Atmos. Chem. Phys., 10, 6063-6086, doi:10.5194/acp-10-60632010, 2010.

Durnford, D., Dastoor, A., Ryzhkov, A., Poissant, L., Pilote, M., and Figueras-Nieto, D.: How relevant is the deposition of mercury onto snowpacks? - Part 2: A modeling study, Atmos. Chem. Phys., 12, 9251-9274, doi:10.5194/acp-12-9251-2012, 2012.

Ebinghaus, R., Kock, H. H., Temme, C., Einax, J. W., Löwe, A. G., Richter, A., Burrows, J. P., and Schroeder, W. H.: Antarctic springtime depletion of atmospheric mercury, Environ. Sci. Technol., 36, 1238-1244, 2002.

Eisele, F., Davis, D. D., Helmig, D., Oltmans, S. J., Neff, W., Huey, G., Tanner, D., Chen, G., Crawford, J. H., Arimoto, R., Buhr, M., Mauldin, L., Hutterli, M., Dibb, J., Blake, D., Brooks, S. B., Johnson, B., Roberts, J. M., Wang, Y., Tan, D., and Flocke, F.: Antarctic tropospheric chemistry (ANTCI) 2003 overview, Atmos. Environ., 2008, 2749-2761, 2008.

Emmons, L. K., Walters, S., Hess, P. G., Lamarque, J.-F., Pfister, G. G., Fillmore, D., Granier, C., Guenther, A., Kinnison, D., Laepple, T., Orlando, J., Tie, X., Tyndall, G., Wiedinmyer, C., Baughcum, S. L., and Kloster, S.: Description and evaluation of the Model for Ozone and Related chemical Tracers, version 4 (MOZART-4), Geosci. Model Dev., 3, 43-67, doi:10.5194/gmd3-43-2010, 2010.

Ferrari, C. P., Gauchard, P.-A., Aspmo, K., Dommergue, A., Magand, O., Bahlmann, E., Nagorski, S., Temme, C., Ebinghaus, R., Steffen, A., Banic, C., Berg, T., Planchon, F., Barbante, C., Cescon, P., and Boutron, C. F.: Snow-to-air exchanges of mercury in an arctic seasonal snowpack in Ny-Alesund, Svalbard, Atmos. Environ., 39, 7633-7645, 2005.

Fisher, J. A., Jacob, D. J., Soerensen, A. L., Amos, H. M., Steffen, A., and Sunderland, E. M.: Riverine source of Arctic Ocean mercury inferred from atmospheric observations, Nature Geosci., 5, 499-504, 2012.

Fisher, J. A., Jacob, D. J., Soerensen, A. L., Amos, H. M., Corbitt, E. S., Streets, D. G., Wang, Q., Yantosca, R. M., and Sunderland, E. M.: Factors driving mercury variability in the Arctic atmosphere and ocean over the past 30 years, Global Biogeochem. Cy., 27, 1226-1235, 2013.

Fitzgerald, W. F. and Gill, G. A.: Subnanogram determination of mercury by two-stage gold amalgamation and gas detection applied to atmospheric analysis, Anal. Chem., 51, 1714-1720, 1979.

Frey, M. M., Brough, N., France, J. L., Anderson, P. S., Traulle, O., King, M. D., Jones, A. E., Wolff, E. W., and Savarino, J.: The diurnal variability of atmospheric nitrogen oxides (NO and $\mathrm{NO}_{2}$ ) above the Antarctic Plateau driven by atmospheric stability and snow emissions, Atmos. Chem. Phys., 13, 3045-3062, doi:10.5194/acp-13-3045-2013, 2013.

Frey, M. M., Roscoe, H. K., Kukui, A., Savarino, J., France, J. L., King, M. D., Legrand, M., and Preunkert, S.: Atmospheric nitrogen oxides ( $\mathrm{NO}$ and $\mathrm{NO}_{2}$ ) at Dome $\mathrm{C}$, East Antarctica, during the OPALE campaign, Atmos. Chem. Phys., 15, 7859-7875, doi:10.5194/acp-15-7859-2015, 2015.

Fujita, K. and Abe, O.: Stable isotopes in daily precipitation at Dome Fuji, East Antarctica, Geophys. Res. Lett., 33, L18503, doi:10.1029/2006GL026936, 2006.

Gallée, H. and Gorodetskaya, I. V.: Validation of a limited area model over Dome C, Antarctic Plateau, during winter, Clim. Dynam., 34, 61-72, 2010.

Gallée, H., Preunkert, S., Argentini, S., Frey, M. M., Genthon, C., Jourdain, B., Pietroni, I., Casasanta, G., Barral, H., Vignon, E., Amory, C., and Legrand, M.: Characterization of the boundary layer at Dome C (East Antarctica) during the OPALE summer campaign, Atmos. Chem. Phys., 15, 62256236, doi:10.5194/acp-15-6225-2015, 2015.

Gårdfeldt, K., Sommar, J., Strömberg, D., and Feng, X.: Oxidation of atomic mercury by hydroxyl radicals and photoinduced decomposition of methylmercury in the aqueous phase, Atmos. Environ., 35, 3039-3047, 2001.

Gauchard, P.-A., Aspmo, K., Temme, C., Steffen, A., Ferrari, C., Berg, T., Ström, J., Kaleschke, L., Dommergue, A., Bahlmann, E., Magand, O., Planchon, F., Ebinghaus, R., Banic, C., Nagorski, S., Baussand, P., and Boutron, C.: Study of the origin of atmospheric mercury depletion events recorded in $\mathrm{Ny}-$ Ålesund, Svalbard, spring 2003, Atmos. Environ., 39, 76207632, doi:10.1016/j.atmosenv.2005.08.010, 2005.

GMOS: Land-based monitoring sites, available at: http://sdi.iia.cnr. it/geoint/publicpage/GMOS/gmos_historical.zul, last access: 27 August 2016.

Goodsite, M., Plane, J. M. C., and Skov, H.: Correction to a theoretical study of the oxidation of $\mathrm{Hg} 0$ to $\mathrm{HgBr} 2$ in the troposphere, Environ. Sci. Technol., 46, 5262-5262, 2012.

Goodsite, M. E., Plane, J. M. C., and Skov, H.: A theoretical study of the oxidation of $\mathrm{Hg}^{0}$ to $\mathrm{HgBr}_{2}$ in the troposphere, Environ. Sci. Technol., 38, 1772-1776, 2004.

Grannas, A. M., Jones, A. E., Dibb, J., Ammann, M., Anastasio, C., Beine, H. J., Bergin, M., Bottenheim, J., Boxe, C. S., Carver, G., Chen, G., Crawford, J. H., Dominé, F., Frey, M. M., Guzmán, M. I., Heard, D. E., Helmig, D., Hoffmann, M. R., Honrath, R. E., Huey, L. G., Hutterli, M., Jacobi, H. W., Klán, P., Lefer, B., McConnell, J., Plane, J., Sander, R., Savarino, J., Shepson, P. B., Simpson, W. R., Sodeau, J. R., von Glasow, R., Weller, R., Wolff, E. W., and Zhu, T.: An overview of snow photochemistry: evidence, mechanisms and impacts, Atmos. Chem. Phys., 7, 43294373, doi:10.5194/acp-7-4329-2007, 2007. 
Grilli, R., Legrand, M., Kukui, A., Méjean, G., Preunkert, S., and Romanini, D.: First investigations of IO, BrO, and NO2 summer atmospheric levels at a coastal East Antarctic site using modelocked cavity enhanced absorption spectroscopy, Geophys. Res. Lett., 40, 791-796, 2013.

Gustin, M. S., Huang, J., Miller, M. B., Peterson, C., Jaffe, D. A., Ambrose, J., Finley, B. D., Lyman, S. N., Call, K., Talbot, R., Feddersen, D., Mao, H., and Lindberg, S. E.: Do we understand what the mercury speciation instruments are actually measuring? Results of RAMIX, Environ. Sci. Technol., 47, 7295-7306, 2013.

Gustin, M. S., Amos, H. M., Huang, J., Miller, M. B., and Heidecorn, K.: Measuring and modeling mercury in the atmosphere: a critical review, Atmos. Chem. Phys., 15, 5697-5713, doi:10.5194/acp-15-5697-2015, 2015.

Gustin, M. S., Evers, D. C., Bank, M. S., Hammerschmidt, C. R., Pierce, A., Basu, N., Blum, J., Bustamante, P., Chen, C., Driscoll, C. T., Horvat, M., Jaffe, D., Pacyna, J., Pirrone, N., and Selin, N.: Importance of Integration and Implementation of Emerging and Future Mercury Research into the Minamata Convention, Environ. Sci. Technol., 50, 2767-2770, doi:10.1021/acs.est.6b00573, 2016.

Hall, B.: The gas phase oxidation of elemental mercury by ozone, Water Air Soil Pollut., 80, 301-315, 1995.

Heidam, N. Z., Wåhlin, P., and Christensen, J. H.: Tropospheric Gases and Aerosols in Northeast Greenland, J. Atmos. Sci., 56, 261-278, doi:10.1175/15200469(1999)056<0261:TGAAIN>2.0.CO;2, 1999.

Heidam, N. Z., Christensen, J., Wåhlin, P., and Skov, H.: Arctic atmospheric contaminants in NE Greenland: levels, variations, origins, transport, transformations and trends 1990-2001, Sci. Total Environ., 331, 5-28, doi:10.1016/j.scitotenv.2004.03.033, 2004.

Heintzenberg, J., Hansson, H. C., and Lannefors, H.: The chemical composition of arctic haze at Ny-Ålesund, Spitsbergen, Tellus, 33, 162-171, doi:10.1111/j.2153-3490.1981.tb01741.x, 1981.

Helmig, D., Oltmans, S. J., Carlson, D., Lamarque, J.-F., Jones, A., Labuschagne, C., Anlauf, K., and Hayden, K.: A review of surface ozone in the polar regions, Atmos. Environ., 41, 5138-5161, 2007.

Hirdman, D., Aspmo, K., Burkhart, J. F., Eckhardt, S., Sodemann, H., and Stohl, A.: Transport of mercury in the Arctic atmosphere: Evidence for a spring-time net sink and summer-time source, Geophys. Res. Lett., 36, L12814, doi:10.1029/2009GL038345, 2009.

Holmes, C. D., Jacob, D. J., Corbitt, E. S., Mao, J., Yang, X., Talbot, R., and Slemr, F.: Global atmospheric model for mercury including oxidation by bromine atoms, Atmos. Chem. Phys., 10, 12037-12057, doi:10.5194/acp-10-12037-2010, 2010.

Huang, J., Miller, M. B., Weiss-Penzias, P., and Gustin, M. S.: Comparison of gaseous oxidized mercury measured by $\mathrm{KCl}$-coated denuders, and nylon and cation exchange membranes, Environ. Sci. Technol., 47, 7307-7316, 2013.

Huang, J., Lyman, S. N., Hartman, J. S., and Gustin, M. S.: A review of passive sampling systems for ambient air mercury measurements, Environmental Science: Processes \& Impacts, 16, 374392, doi:10.1039/C3EM00501A, 2014.

Jaffe, D. A., Lyman, S., Amos, H. M., Gustin, M. S., Huang, J., Selin, N. E., Levin, L., Schure, A., Mason, R. P., Talbot, R., Rutter, A. P., Finley, B., Jaeglé, L., Shah, V., McClure, C., Ambrose,
J., Gratz, L., Lindberg, S. E., Weiss-Penzias, P., Sheu, G.-R., Feddersen, D., Horvat, M., Dastoor, A., Hynes, A. J., Mao, H., Sonke, J. E., Slemr, F., Fisher, J. A., Ebinghaus, R., Zhang, B., and Edwards, D. P.: Progress on understanding atmospheric mercury hampered by uncertain measurements, Environ. Sci. Technol., 48, 7204-7206, doi:10.1021/es5026432, 2014.

Jin, M., Deal, C., Lee, S. H., Elliott, S., Hunke, E., Maltrud, M., and Jeffery, N.: Investigation of Arctic sea ice and ocean primary production for the period 1992-2007 using a 3-D global ice-ocean ecosystem model, Deep Sea Res. II, 81-84, 28-35, doi:10.1016/j.dsr2.2011.06.003, 2012.

Jones, C. P., Lyman, S. N., Jaffe, D. A., Allen, T., and O’Neil, T. L.: Detection and quantification of gas-phase oxidized mercury compounds by GC/MS, Atmos. Meas. Tech., 9, 2195-2205, doi:10.5194/amt-9-2195-2016, 2016.

Jung, G., Hedgecock, I. M., and Pirrone, N.: ECHMERIT V1.0 - a new global fully coupled mercury-chemistry and transport model, Geosci. Model Dev., 2, 175-195, doi:10.5194/gmd-2175-2009, 2009.

Kirk, J. L., St. Louis, V. L., and Sharp, M. J.: Rapid Reduction and Reemission of Mercury Deposited into Snowpacks during Atmospheric Mercury Depletion Events at Churchill, Manitoba, Canada, Environ. Sci. Technol., 40, 7590-7596, doi:10.1021/es061299+, 2006.

Koop, T., Kapilashrami, A., Molina, L. T., and Molina, M. J.: Phase transitions of sea-salt/water mixtures at low temperatures: implications for ozone chemistry in the polar marine boundary layer, J. Geophys. Res., 105, 26393-26402, doi:10.1029/2000JD900413, 2000.

Kos, G., Ryzhkov, A., Dastoor, A., Narayan, J., Steffen, A., Ariya, P. A., and Zhang, L.: Evaluation of discrepancy between measured and modelled oxidized mercury species, Atmos. Chem. Phys., 13, 4839-4863, doi:10.5194/acp-13-4839-2013, 2013.

Kukui, A., Legrand, M., Ancellet, G., Gros, V., Bekki, S., SardaEstève, R., Loisil, R., and Preunkert, S.: Measurements of $\mathrm{OH}$ and $\mathrm{RO} 2$ radicals at the coastal Antarctic site of Dumont d'Urville (East Antarctica) in summer 2010-2011, J. Geophys. Res., 117, D12310, doi:10.1029/2012JD017614, 2012.

Kukui, A., Legrand, M., Preunkert, S., Frey, M. M., Loisil, R., Gil Roca, J., Jourdain, B., King, M. D., France, J. L., and Ancellet, G.: Measurements of $\mathrm{OH}$ and $\mathrm{RO}_{2}$ radicals at Dome C, East Antarctica, Atmos. Chem. Phys., 14, 12373-12392, doi:10.5194/acp-14-12373-2014, 2014.

Kwon, S. Y. and Selin, N. E.: Uncertainties in Atmospheric Mercury Modeling for Policy Evaluation, Current Pollution Reports, 2, 103-114, doi:10.1007/s40726-016-0030-8, 2016.

Lamborg, C. H., Hammerschmidt, C. R., Bowman, K. L., Swarr, G. J., Munson, K. M., Ohnemus, D. C., Lam, P. J., Heimbürger, L.-E., Rikjenberg, M. J. A., and Saito, M. A.: A global ocean inventory of anthropogenic mercury based on water column measurements, Nature, 512, 65-69, doi:10.1038/nature13563, 2014.

Larose, C., Dommergue, A., De Angelis, M., Cossa, D., Averty, B., Marusczak, N., Soumis, N., Schneider, D., and Ferrari, C.: Springtime changes in snow chemistry lead to new insights into mercury methylation in the Arctic, Geochim. Cosmochim. Acta, 74, 6263-6275, 2010.

Legrand, M., Preunkert, S., Jourdain, B., Gallée, H., Goutail, F., Weller, R., and Savarino, J.: Year-round record of surface ozone at coastal (Dumont d'Urville) and inland (Concor- 
dia) sites in east antarctica, J. Geophys. Res., 114, D20306, doi:10.1029/2008JD011667, 2009.

Legrand, M., Yang, X., Preunkert, S., and Theys, N.: Year-round records of sea salt, gaseous, and particulate inorganic bromine in the atmospheric boundary layer at coastal (Dumont d'Urville) and central (Concordia) East Antarctic sites, J. Geophys. Res.Atmos., 121, 997-1023, doi:10.1002/2015JD024066, 2016a.

Legrand, M., Preunkert, S., Savarino, J., Frey, M. M., Kukui, A., Helmig, D., Jourdain, B., Jones, A. E., Weller, R., Brough, N., and Gallée, H.: Inter-annual variability of surface ozone at coastal (Dumont d'Urville, 2004-2014) and inland (Concordia, 2007-2014) sites in East Antarctica, Atmos. Chem. Phys., 16, 8053-8069, doi:10.5194/acp-16-8053-2016, 2016 b.

Lin, C.-J. and Pehkonen, S. O.: The chemistry of atmospheric mercury: a review, Atmos. Environ., 33, 2067-2079, 1999.

Lin, J.-T. and McElroy, M. B.: Impacts of boundary layer mixing on pollutant vertical profiles in the lower troposphere: Implications to satellite remote sensing, Atmos. Environ., 44, 17261739, doi:10.1016/j.atmosenv.2010.02.009, 2010.

Lindberg, S. E. and Stratton, W. J.: Atmospheric mercury speciation: concentrations and behavior of reactive gaseous mercury in ambient air, Environ. Sci. Technol., 32, 49-57, 1998.

Lindberg, S. E., Brooks, S., Lin, C.-J., Scott, K., Meyers, T., Chambers, L., Landis, M., and Stevens, R.: Formation of Reactive Gaseous Mercury in the Arctic: Evidence of Oxidation of $\mathrm{Hg} 0$ to Gas-Phase Hg-II Compounds after Arctic Sunrise, Water Air Soil Pollut. Focus, 1, 295-302, doi:10.1023/a:1013171509022, 2001.

Lindberg, S. E., Brooks, S., Lin, C.-J., Scott, K. J., Landis, M. S., Stevens, R. K., Goodsite, M. E., and Richter, A.: Dynamic oxidation of gaseous mercury in the arctic troposphere at polar sunrise, Environ. Sci. Technol., 36, 1245-1256, 2002.

Lindqvist, O. and Rodhe, H.: Atmospheric mercury - a review, Tellus, 37B, 136-159, 1985.

Liu, G.: Deriving snow cloud characteristics from CloudSat observations, J. Geophys. Res., 113, D00A09, doi:10.1029/2007JD009766, 2008.

Lu, J. Y., Schroeder, W. H., Barrie, L. A., Steffen, A., Welch, H. E., Martin, K., Lockhart, L., Hunt, R. V., Boila, G., and Richter, A.: Magnification of atmospheric mercury deposition to polar regions in springtime: the link to tropospheric ozone depletion chemistry, Geophys. Res. Lett., 28, 3219-3222, 2001.

Lyman, S. N., Jaffe, D. A., and Gustin, M. S.: Release of mercury halides from $\mathrm{KCl}$ denuders in the presence of ozone, Atmos. Chem. Phys., 10, 8197-8204, doi:10.5194/acp-10-81972010, 2010.

Lynch, J. A., Horner, K. S., and Grimm, J. W.: Atmospheric deposition: spatial and temporal variations in Pennsylvania 2002, Penn State Institutes of the Environment, The Pennsylvania State University, University Park, PA, 231, 2003.

Maturilli, M., Herber, A., and König-Langlo, G.: Climatology and time series of surface meteorology in Ny-Ålesund, Svalbard, Earth Syst. Sci. Data, 5, 155-163, doi:10.5194/essd-5-155-2013, 2013.

Moore, C. W., Obrist, D., Steffen, A., Staebler, R. M., Douglas, T. A., Richter, A., and Nghiem, S. V.: Convective forcing of mercury and ozone in the Arctic boundary layer induced by leads in sea ice, Nature, 506, 81-84, doi:10.1038/nature12924, 2014.
Munthe, J.: The aqueous oxidation of elemental mercury by ozone, Atmos. Environ., 26, 1461-1468, 1992.

Nash, J. E. and Sutcliffe, J. V.: River flow forecasting through conceptual models part I - A discussion of principles, J. Hydrol., 10, 282-290, doi:10.1016/0022-1694(70)90255-6, 1970.

Neff, W., Helmig, D., Grachev, A. A., and Davis, D.: A study of boundary layer behavior associated with high NO concentrations at the South Pole using a minisodar, tethered balloon, and sonic anemometer, Atmos. Environ., 42, 2762-2779, 2008.

Nerentorp Mastromonaco, M., Gårdfeldt, K., Jourdain, B., Abrahamsson, K., Granfors, A., Ahnoff, M., Dommergue, A., Méjean, G., and Jacobi, H.-W.: Antarctic winter mercury and ozone depletion events over sea ice, Atmos. Environ., 129, 125-132, 2016.

Neuman, J. A., Nowak, J. B., Huey, L. G., Burkholder, J. B., Dibb, J. E., Holloway, J. S., Liao, J., Peischl, J., Roberts, J. M., Ryerson, T. B., Scheuer, E., Stark, H., Stickel, R. E., Tanner, D. J., and Weinheimer, A.: Bromine measurements in ozone depleted air over the Arctic Ocean, Atmos. Chem. Phys., 10, 6503-6514, doi:10.5194/acp-10-6503-2010, 2010.

Nguyen, Q. T., Skov, H., Sørensen, L. L., Jensen, B. J., Grube, A. G., Massling, A., Glasius, M., and Nøjgaard, J. K.: Source apportionment of particles at Station Nord, North East Greenland during 2008-2010 using COPREM and PMF analysis, Atmos. Chem. Phys., 13, 35-49, doi:10.5194/acp-13-35-2013, 2013.

O’Driscoll, N. J., Siciliano, S. D., Lean, D. R. S., and Amyot, M.: Gross photoreduction kinetics of mercury in temperate freshwater lakes and rivers: application to a general model of DGM dynamics, Environ. Sci. Technol., 40, 837-843, 2006.

Palerme, C., Kay, J. E., Genthon, C., L'Ecuyer, T., Wood, N. B., and Claud, C.: How much snow falls on the Antarctic ice sheet?, The Cryosphere, 8, 1577-1587, doi:10.5194/tc-8-1577-2014, 2014.

Parish, T. R. and Bromwich, D. H.: The surface windfield over the Antarctic ice sheets, Nature, 328, 51-54, 1987.

Parish, T. R. and Bromwich, D. H.: Reexamination of the nearsurface airflow over the Antarctic continent and implications on atmospheric circulations at high southern latitudes, Mon. Weather Rev., 135, 1961-1973, 2007.

Parrella, J. P., Jacob, D. J., Liang, Q., Zhang, Y., Mickley, L. J., Miller, B., Evans, M. J., Yang, X., Pyle, J. A., Theys, N., and Van Roozendael, M.: Tropospheric bromine chemistry: implications for present and pre-industrial ozone and mercury, Atmos. Chem. Phys., 12, 6723-6740, doi:10.5194/acp-12-6723-2012, 2012.

Petersen, G., Munthe, J., Pleijel, K., Bloxam, R., and Kumar, A. V.: A comprehensive Eulerian modeling framework for airborne mercury species: Development and testing of the Tropospheric Chemistry module (TCM), Atmos. Environ., 32, 829843, doi:10.1016/S1352-2310(97)00049-6, 1998.

Pfaffhuber, K. A., Berg, T., Hirdman, D., and Stohl, A.: Atmospheric mercury observations from Antarctica: seasonal variation and source and sink region calculations, Atmos. Chem. Phys., 12, 3241-3251, doi:10.5194/acp-12-3241-2012, 2012.

Pietroni, I., Argentini, S., Petenko, I., and Sozzi, R.: Measurements and parametrizations of the atmospheric boundary-layer height at Dome C, Antarctica, Bound.-Lay. Meteorol., 143, 189-206, 2012.

Platt, U. and Janssen, C.: Observation and role of the free radicals $\mathrm{NO}_{3}, \mathrm{ClO}, \mathrm{BrO}$ and $\mathrm{IO}$ in the troposphere, Faraday Discuss., 100, 175-198, 1995. 
Poissant, L. and Pilote, M.: Time series analysis of atmospheric mercury in Kuujjuarapik/Whapmagoostui (Québec), J. Phys. IV France, 107, 1079-1082, 2003.

Poulain, A. J., Lalonde, J. D., Amyot, M., Shead, J. A., Raofie, F., and Ariya, P. A.: Redox transformations of mercury in an Arctic snowpack at springtime, Atmos. Environ., 38, 6763-6774, 2004.

Prestbo, E. M. and Gay, D. A.: Wet deposition of mercury in the U.S. and Canada, 1996-2005: Results and analysis of the NADP mercury deposition network (MDN), Atmos. Environ., 43, 42234233, doi:10.1016/j.atmosenv.2009.05.028, 2009.

Saiz-Lopez, A., Mahajan, A. S., Salmon, R. A., Bauguitte, S. J.-B., Jones, A. E., Roscoe, H. K., and Plane, J. M. C.: Boundary layer halogens in coastal antarctica, Science, 317, 348-351, 2007.

Sander, R., Burrows, J., and Kaleschke, L.: Carbonate precipitation in brine - a potential trigger for tropospheric ozone depletion events, Atmos. Chem. Phys., 6, 4653-4658, doi:10.5194/acp-64653-2006, 2006.

Savarino, J., Kaiser, J., Morin, S., Sigman, D. M., and Thiemens, M. H.: Nitrogen and oxygen isotopic constraints on the origin of atmospheric nitrate in coastal Antarctica, Atmos. Chem. Phys., 7, 1925-1945, doi:10.5194/acp-7-1925-2007, 2007.

Schroeder, W. H., Anlauf, K. G., Barrie, L. A., Lu, J. Y., Steffen, A., Schneeberger, D. R., and Berg, T.: Arctic spingtime depletion of mercury, Nature, 394, 331-332, 1998

Selin, N. E.: Global biogeochemical cycling of mercury: a review, Annual Review of Environment and Resources, 34, 43-63, 2009.

Selin, N. E., Jacob, D. J., Yantosca, R. M., Strode, S., Jaeglé, L., and Sunderland, E. M.: Global 3-D land-ocean-atmosphere model for mercury: present-day versus preindustrial cycles and anthropogenic enrichment factors for deposition, Global Biogeochem. Cy., 22, GB2011, doi:10.1029/2007GB003040, 2008.

Shaw, G. E.: Evidence for a central Eurasian source area of Arctic haze in Alaska, Nature, 299, 815-818, doi:10.1038/299815a0, 1982

Skamarock, W. C., Klemp, J. B., Dudhia, J., Gill, D. O., Barker, D. M., Wang, W., and Powers, J. G.: A description of the advanced research WRF version 2, NCAR/TN-468+STR, NCAR Technical Note, Boulder, CO, USA, 2007.

Skov, H., Christensen, J. H., Goodsite, M. E., Heidam, N. Z., Jensen, B., Wåhlin, P., and Geernaert, G.: Fate of Elemental Mercury in the Arctic during Atmospheric Mercury Depletion Episodes and the Load of Atmospheric Mercury to the Arctic, Environ. Sci. Technol., 38, 2373-2382, doi:10.1021/es030080h, 2004.

Slemr, F., Angot, H., Dommergue, A., Magand, O., Barret, M., Weigelt, A., Ebinghaus, R., Brunke, E.-G., Pfaffhuber, K. A., Edwards, G., Howard, D., Powell, J., Keywood, M., and Wang, F.: Comparison of mercury concentrations measured at several sites in the Southern Hemisphere, Atmos. Chem. Phys., 15, 31253133, doi:10.5194/acp-15-3125-2015, 2015.

Soerensen, A. L., Sunderland, E. M., Holmes, C. D., Jacob, D. J., Yantosca, R. M., Skov, H., Christensen, J. H., Strode, S. A., and Mason, R. P.: An improved global model for air-sea exchange of mercury: high concentrations over the north atlantic, Environ. Sci. Technol., 44, 8574-8580, 2010.

Soerensen, A. L., Jacob, D. J., Schartup, A. T., Fisher, J. A., Lehnherr, I., St. Louis, V. L., Heimbürger, L.-E., Sonke, J. E., Krabbenhoft, D. P., and Sunderland, E. M.: A mass budget for mercury and methylmercury in the Arctic Ocean, Global Biogeochem. Cy., 30, 560-575, doi:10.1002/2015GB005280, 2016.

Sommar, J., Gårdfeldt, K., Strömberg, D., and Feng, X.: A kinetic study of the gas-phase reactions between the hydroxyl radical and atomic mercury, Atmos. Environ., 35, 3049-3054, 2001.

Sommar, J., Wängberg, I., Berg, T., Gårdfeldt, K., Munthe, J., Richter, A., Urba, A., Wittrock, F., and Schroeder, W. H.: Circumpolar transport and air-surface exchange of atmospheric mercury at $\mathrm{Ny}-\AA$ Ålesund $\left(79^{\circ} \mathrm{N}\right)$, Svalbard, spring 2002, Atmos. Chem. Phys., 7, 151-166, doi:10.5194/acp-7-151-2007, 2007.

Sommar, J., Andersson, M. E., and Jacobi, H.-W.: Circumpolar measurements of speciated mercury, ozone and carbon monoxide in the boundary layer of the Arctic Ocean, Atmos. Chem. Phys., 10, 5031-5045, doi:10.5194/acp-10-5031-2010, 2010.

Song, S., Selin, N. E., Soerensen, A. L., Angot, H., Artz, R., Brooks, S., Brunke, E.-G., Conley, G., Dommergue, A., Ebinghaus, R., Holsen, T. M., Jaffe, D. A., Kang, S., Kelley, P., Luke, W. T., Magand, O., Marumoto, K., Pfaffhuber, K. A., Ren, X., Sheu, G.-R., Slemr, F., Warneke, T., Weigelt, A., Weiss-Penzias, P., Wip, D. C., and Zhang, Q.: Top-down constraints on atmospheric mercury emissions and implications for global biogeochemical cycling, Atmos. Chem. Phys., 15, 7103-7125, doi:10.5194/acp-157103-2015, 2015.

Spreen, G., Kaleschke, L., and Heygster, G.: Sea ice remote sensing using AMSR-E $89 \mathrm{GHz}$ channels, J. Geophys. Res., 113, C02S03, doi:10.1029/2005JC003384, 2008.

Sprovieri, F., Pirrone, N., Hedgecock, I. M., Landis, M. S., and Stevens, R. K.: Intensive atmospheric mercury measurements at Terra Nova Bay in antarctica during November and December 2000, J. Geophys. Res., 107, 4722, doi:10.1029/2002JD002057, 2002.

Sprovieri, F., Pirrone, N., Landis, M. S., and Stevens, R. K.: Oxidation of Gaseous Elemental Mercury to Gaseous Divalent Mercury during 2003 Polar Sunrise at Ny-Alesund, Environ. Sci Technol., 39, 9156-9165, doi:10.1021/es050965o, 2005a.

Sprovieri, F., Pirrone, N., Landis, M. S., and Stevens, R. K.: Atmospheric mercury behavior at different altitudes at Ny Alesund during Spring 2003, Atmos. Environ., 39, 7646-7656, doi:10.1016/j.atmosenv.2005.08.001, 2005b.

Sprovieri, F., Pirrone, N., Ebinghaus, R., Kock, H., and Dommergue, A.: A review of worldwide atmospheric mercury measurements, Atmos. Chem. Phys., 10, 8245-8265, doi:10.5194/acp10-8245-2010, 2010.

Sprovieri, F., Pirrone, N., Bencardino, M., D’Amore, F., Carbone, F., Cinnirella, S., Mannarino, V., Landis, M., Ebinghaus, R., Weigelt, A., Brunke, E.-G., Labuschagne, C., Martin, L., Munthe, J., Wängberg, I., Artaxo, P., Morais, F., Cairns, W., Barbante, C., Diéguez, M. D. C., Garcia, P. E., Dommergue, A., Angot, H., Magand, O., Skov, H., Horvat, M., Kotnik, J., Read, K. A., Neves, L. M., Gawlik, B. M., Sena, F., Mashyanov, N., Obolkin, V. A., Wip, D., Feng, X. B., Zhang, H., Fu, X., Ramachandran, R., Cossa, D., Knoery, J., Marusczak, N., Nerentorp, M., and Norstrom, C.: Atmospheric Mercury Concentrations observed at ground-based monitoring sites globally distributed in the framework of the GMOS network, Atmos. Chem. Phys. Discuss., doi:10.5194/acp-2016-466, in review, 2016a.

Sprovieri, F., Pirrone, N., Bencardino, M., D'Amore, F., Angot, H., Barbante, C., Brunke, E.-G., Arcega-Cabrera, F., Cairns, W., Comero, S., Diéguez, M. D. C., Dommergue, A., Ebinghaus, R., 
Feng, X. B., Fu, X., Garcia, P. E., Gawlik, B. M., Hageström, U., Hansson, K., Horvat, M., Kotnik, J., Labuschagne, C., Magand, O., Martin, L., Mashyanov, N., Mkololo, T., Munthe, J., Obolkin, V., Islas, M. R., Sena, F., Somerset, V., Spandow, P., Vardè, M., Walters, C., Wängberg, I., Weigelt, A., Yang, X., and Zhang, H.: Five-year records of Total Mercury Deposition flux at GMOS sites in the Northern and Southern Hemispheres, Atmos. Chem. Phys. Discuss., doi:10.5194/acp-2016-517, in review, 2016 b.

Steen, A. O., Berg, T., Dastoor, A. P., Durnford, D. A., Hole, L. R., and Pfaffhuber, K. A.: Dynamic exchange of gaseous elemental mercury during polar night and day, Atmos. Environ., 43, 56045610, doi:10.1016/j.atmosenv.2009.07.069, 2009.

Steen, A. O., Berg, T., Dastoor, A. P., Durnford, D. A., Engelsen, O., Hole, L. R., and Pfaffhuber, K. A.: Natural and anthropogenic atmospheric mercury in the European Arctic: a fractionation study, Atmos. Chem. Phys., 11, 6273-6284, doi:10.5194/acp-11-62732011, 2011.

Steffen, A., Schroeder, W., Bottenheim, J., Narayan, J., and Fuentes, J. D.: Atmospheric mercury concentrations: measurements and profiles near snow and ice surfaces in the Canadian Arctic during Alert 2000, Atmos. Environ., 36, 2653-2661, 2002.

Steffen, A., Schroeder, W. H., Edwards, G., and Banic, C.: Mercury throughout polar sunrise 2002, J. Phys. IV France, 107, 12671270, 2003.

Steffen, A., Schroeder, W., Macdonald, R., Poissant, L., and Konoplev, A.: Mercury in the Arctic atmosphere: An analysis of eight years of measurements of GEM at Alert (Canada) and a comparison with observations at Amderma (Russia) and Kuujjuarapik (Canada), Sci. Total Environ., 342, 185-198, doi:10.1016/j.scitotenv.2004.12.048, 2005.

Steffen, A., Douglas, T., Amyot, M., Ariya, P., Aspmo, K., Berg, T., Bottenheim, J., Brooks, S., Cobbett, F., Dastoor, A., Dommergue, A., Ebinghaus, R., Ferrari, C., Gardfeldt, K., Goodsite, M. E., Lean, D., Poulain, A. J., Scherz, C., Skov, H., Sommar, J., and Temme, C.: A synthesis of atmospheric mercury depletion event chemistry in the atmosphere and snow, Atmos. Chem. Phys., 8, 1445-1482, doi:10.5194/acp-8-1445-2008, 2008.

Steffen, A., Scherz, T., Oslon, M., Gay, D. A., and Blanchard, P.: A comparison of data quality control protocols for atmospheric mercury speciation measurements, J. Environ. Monit., 14, 752765, doi:10.1039/c2em10735j, 2012.

Steffen, A., Bottenheim, J., Cole, A., Ebinghaus, R., Lawson, G., and Leaitch, W. R.: Atmospheric mercury speciation and mercury in snow over time at Alert, Canada, Atmos. Chem. Phys., 14, 2219-2231, doi:10.5194/acp-14-2219-2014, 2014.

Steffen, A., Lehnherr, I., Cole, A., Ariya, P., Dastoor, A., Durnford, D., Kirk, J., and Pilote, M.: Atmospheric mercury in the Canadian Arctic. Part I: A review of recent field measurements, Sci. Total Environ., 509-510, 3-15, doi:10.1016/j.scitotenv.2014.10.109, 2015.

Stephens, G. L., Vane, D. G., Tanelli, S., Eastwood, I., Durden, S., Rokey, M., Reinke, D., Partain, P., Mace, G. G., Austin, R., L'Ecuyer, T., Haynes, J., Lebsock, M., Suzuki, K., Waliser, D., Wu, D., Kay, J., Gettelman, A., Wang, Z., and Marchand, R.: CloudSat mission: performance and early science after the first year of operation, J. Geophys. Res., 113, D00A18, doi:10.1029/2008JD009982, 2008.

Subir, M., Ariya, P. A., and Dastoor, A.: A review of uncertainties in atmospheric modeling of mercury chemistry I. Uncertain- ties in existing kinetic parameters - fundamental limitations and the importance of heteregeneous chemistry, Atmos. Environ., 45, 5664-5675, 2011.

Subir, M., Ariya, P. A., and Dastoor, A.: A review of the sources of uncertainties in atmospheric mercury modeling II. Mercury surface and heterogeneous chemistry - a missing link, Atmos. Environ., 46, 1-10, 2012.

Tarasick, D. W. and Bottenheim, J. W.: Surface ozone depletion episodes in the Arctic and Antarctic from historical ozonesonde records, Atmos. Chem. Phys., 2, 197-205, doi:10.5194/acp-2197-2002, 2002.

Tekran: Tekran 2537 mercury monitor detection limit, Summary of known estimates, Tekran Instruments Corp., Toronto, ON, Canada, 2011.

Temme, C., Einax, J. W., Ebinghaus, R., and Schroeder, W. H.: Measurements of atmospheric mercury species at a coastal site in the antarctic and over the atlantic ocean during polar summer, Environ. Sci. Technol., 37, 22-31, 2003.

Theys, N., Van Roozendael, M., Hendrick, F., Yang, X., De Smedt, I., Richter, A., Begoin, M., Errera, Q., Johnston, P. V., Kreher, K., and De Mazière, M.: Global observations of tropospheric BrO columns using GOME-2 satellite data, Atmos. Chem. Phys., 11, 1791-1811, doi:10.5194/acp-11-1791-2011, 2011.

Tossell, J. A.: Calculation of the energetics for oxidation of gasphase elemental $\mathrm{Hg}$ by $\mathrm{Br}$ and $\mathrm{BrO}$, J. Phys. Chem. A, 107, 7804-7808, 2003.

Toyota, K., Dastoor, A. P., and Ryzhkov, A.: Air-snowpack exchange of bromine, ozone and mercury in the springtime Arctic simulated by the 1-D model PHANTAS - Part 2: Mercury and its speciation, Atmos. Chem. Phys., 14, 4135-4167, doi:10.5194/acp-14-4135-2014, 2014.

Travnikov, O. and Ilyin, I.: The EMEP/MSC-E Mercury Modelling System, in: Mercury Fate and Transport in the Global Atmosphere: Emissions, Measurements, and Models, edited by: Pirrone, N. and Mason, R. P., Springer, 571-587, 2009.

Travnikov, O., Dastoor, A., De Simone, F., Hedgecock, I. M., Pirrone, N., Ryjkov, A., Selin, N. E., Song, S., and Yang, X.: Multimodel study of mercury dispersion in the atmosphere: Atmospheric processes and model evaluation, in preparation, 2016.

UNEP: Text of the Minamata Convention on Mercury for adoption by the Conference of Plenipotentiaries. unep.org. July 31, available at: http://www.unep.org/hazardoussubstances/ Portals/9/Mercury/Documents/dipcon/CONF_3_Minamata\% 20Convention\%20on\%20Mercury_final\%2026\%2008_e.pdf, last access: 27 March 2016, $2013 \mathrm{a}$.

UNEP: Global Mercury Assessment 2013: Sources, Emissions, Releases and Environmental Transport. UNEP Chemicals Branch, Geneva, Switzerland, 44 pp., 2013 b.

UNEP: Global mercury modelling: update of modelling results in the global mercury assessment 2013, 2015.

Wang, J., Zhang, L., and Xie, Z.: Total gaseous mercury along a transect from coastal to central Antarctic: Spatial and diurnal variations, J. Hazard. Materials, 317, 362-372, doi:10.1016/j.jhazmat.2016.05.068, 2016.

Wang, P.: Atmospheric mercury speciation and aerosol properties at Ny-Alesund, Department of Chemistry, Norwegian University of Science and Technology, 130 pp., 2015.

Yang, X., Cox, R. A., Warwick, N. J., Pyle, J. A., Carver, G. D., O'Connor, F. M., and Savage, N. H.: Tropospheric bromine 
chemistry and its impacts on ozone: A model study, J. Geophys. Res., 110, D23311, doi:10.1029/2005JD006244, 2005.

Yu, J., Xie, Z., Kang, H., Li, Z., Sun, C., Bian, L., and Zhang, P.: High variability of atmospheric mercury in the summertime boundary layer through the central Arctic Ocean, Scientific Reports, 4, 6091, doi:10.1038/srep06091, 2014.

Zambrano-Bigiarini, M.: hydroGOF: Goodness-of-fit functions for comparison of simulated and observed hydrological time series, $\mathrm{R}$ package version $0.3-8$, available at: http://CRAN.R-project. org/package=hydroGOF (last access: June 2016), 2014.

Zatko, M., Geng, L., Alexander, B., Sofen, E., and Klein, K.: The impact of snow nitrate photolysis on boundary layer chemistry and the recycling and redistribution of reactive nitrogen across Antarctica and Greenland in a global chemical transport model, Atmos. Chem. Phys., 16, 2819-2842, doi:10.5194/acp-16-28192016, 2016.
Zatko, M. C., Grenfell, T. C., Alexander, B., Doherty, S. J., Thomas, J. L., and Yang, X.: The influence of snow grain size and impurities on the vertical profiles of actinic flux and associated $\mathrm{NO}_{x}$ emissions on the Antarctic and Greenland ice sheets, Atmos. Chem. Phys., 13, 3547-3567, doi:10.5194/acp-13-35472013, 2013.

Zhu, W., Lin, C.-J., Wang, X., Sommar, J., Fu, X., and Feng, X.: Global observations and modeling of atmosphere-surface exchange of elemental mercury: a critical review, Atmos. Chem. Phys., 16, 4451-4480, doi:10.5194/acp-16-4451-2016, 2016. 